\title{
Vascular involvement in systemic sclerosis (scleroderma)
}

This article was published in the following Dove Press journal:

Journal of Inflammation Research

25 June 2011

Number of times this article has been viewed

\section{Debendra Pattanaik' \\ Monica Brown ${ }^{2}$ \\ Arnold E Postlethwaite \\ 'Division of Connective Tissue Diseases, Department of Medicine; ${ }^{2}$ Section of Pediatric Rheumatology Department of Pediatrics, University of Tennessee Health Science Center, and Department of Veterans Affairs Medical Center, Memphis, TN, USA}

Correspondence: Arnold E Postlethwaite The University of Tennessee Health Science Center, 956 Court Avenue, Room G326, Memphis, TN 38163, USA

Tel + I 90I 4485774

Fax + I 90I 4487265

Email apostlethwai@uthsc.edu

\begin{abstract}
Systemic sclerosis (SSc) is an acquired multiorgan connective tissue disease with variable mortality and morbidity dictated by clinical subset type. The etiology of the basic disease and pathogenesis of the systemic autoimmunity, fibrosis, and fibroproliferative vasculopathy are unknown and debated. In this review, the spectrum of vascular abnormalities and the options currently available to treat the vascular manifestations of SSc are discussed. Also discussed is how the hallmark pathologies (ie, how autoimmunity, vasculopathy, and fibrosis of the disease) might be effected and interconnected with modulatory input from lysophospholipids, sphingosine 1-phosphate, and lysophosphatidic acid.
\end{abstract}

Keywords: fibrosis, autoimmunity, vasculopathy, S1P, LPA

\section{Introduction}

Systemic sclerosis ( $\mathrm{SSc}$ ) is a connective tissue disease of unknown etiology with multiorgan involvement and a wide range of clinical manifestations. The incidence of SSc is about 20 cases per million population per year, and the prevalence is more than 250 patients per million population in the USA. ${ }^{1}$ Major organ involvement is associated with decreased survival in SSc. In one study, 9-year survival in SSc was about 39\% when a major organ (skin, gastrointestinal [GI] tract, lung, kidney, and heart) is involved compared with $72 \%$ in case of mild or no organ involvement. ${ }^{2}$ The primary cause of death in SSc is now the lung. Pulmonary fibrosis and pulmonary hypertension $(\mathrm{PH})$ cause more than half of all SSc-related deaths. ${ }^{1}$ The characteristic features of SSc include extensive fibrosis, fibroproliferative vasculopathy, systemic autoimmunity (autoantibodies and $\mathrm{T}$ cell autoantigen reactivity) and inflammation. There are two major forms of SSc: limited cutaneous (lcSSc) and diffuse cutaneous (dcSSc). These two forms differ mainly with regard to extent of skin involvement, autoantibody association, and the pattern of organ involvement (Table 1). In lcSSc, fibrosis of skin occurs on face and chest and distal elbows and knees, and it is associated with anticentromere antibody. Pulmonary hypertension is more common in lcSSc. In $\mathrm{dcSSc}$, the skin involvement is more widespread, and it is associated with anti-DNA topoisomerase I (Scl-70) antibody. Pulmonary fibrosis and scleroderma renal crisis are more commonly associated with dcSSc. A third, less common form "SSc sine scleroderma" is also recognized, in which there is internal organ involvement with occasional fibrosis of distal digits. Although SSc is considered a fibrosing disease, vascular involvement plays a major role in pathogenesis and organ dysfunction. SSc vascular disease involves vasculopathy with luminal occlusion, thrombosis, and vasospasm. 
Table I Important differences between IcSSc and dcSSc

\begin{tabular}{|c|c|c|}
\hline Features & LcSSc & dcSSc \\
\hline Skin & $\begin{array}{l}\text { Skin thickening occurs late; limited to distal part of } \\
\text { upper and lower extremities, face, neck, and upper chest. } \\
\text { Telangiectasias and calcinosis are common. } \\
\text { Tendon friction rub not seen. }\end{array}$ & $\begin{array}{l}\text { Skin thickening occurs early; moves up to } \\
\text { proximal part of extremities and trunk. } \\
\text { Telangiectasias and calcinosis may occur } \\
\text { late in disease. } \\
\text { Tendon friction rub present. }\end{array}$ \\
\hline GI & $\begin{array}{l}\text { Esophageal dysmotility is more common than } \\
\text { small and large intestine involvement. }\end{array}$ & $\begin{array}{l}\text { Esophageal dysmotility is frequently seen. } \\
\text { Small and large intestinal involvement } \\
\text { is more common. }\end{array}$ \\
\hline Pulmonary & $\begin{array}{l}\text { Pulmonary fibrosis is less frequent and less severe. } \\
\text { Frequent and severe pulmonary hypertension } \\
\text { are more common. }\end{array}$ & $\begin{array}{l}\text { Pulmonary fibrosis is more common and severe. } \\
\text { Pulmonary hypertension is less frequent. }\end{array}$ \\
\hline Kidney & Renal crisis uncommon & Renal crisis is more frequent. \\
\hline Autoantibody association & Anticentromere antibodies are predominant. & $\begin{array}{l}\text { Anti-Scl-70 antibody is predominant. } \\
\text { Anti-RNA polymerase antibody is more common. }\end{array}$ \\
\hline
\end{tabular}

Abbreviations: dcSSc, diffuse cutaneous systemic sclerosis; Gl, gastrointestinal; IcSSc, limited cutaneous systemic sclerosis.

Complex interactions between endothelial cells, vascular smooth muscle cells, extracellular matrix and circulating mediators contribute to vascular remodeling, vasospasm, and vessel occlusion. This article focuses primarily on the vascular aspects of SSc and how two lysophospholipids (sphingosine 1-phosphate [S1P] and lysophosphatidic acid [LPA]) recently shown to be elevated in SSc sera might assume roles in mediating vascular changes, autoimmunity, and fibrosis in the disease.

\section{Mechanisms of SSc pathogenesis Genetic associations}

Current data indicate that $\mathrm{SSc}$ is a polygenic autoimmune disease with overlap of some susceptibility loci with other autoimmune diseases. Most notably, protein tyrosine phosphatase, nonreceptor type 22 (PTPN22) and signal transducers and activators of transcription-4 (STAT4) are associated not only with SSc but also with rheumatoid arthritis and systemic lupus erythematosus. ${ }^{3}$ Interferon regulating factor 5 (IRF5) and B cell scaffold protein with ankryn repeats $(B A N K 1)$ polymorphisms have been associated with SSc. ${ }^{4}$ Several studies show some weak association of SSc with certain major histocompatibility complex (MHC) or human leukocyte antigen class II (human leukocyte antigen [HLA]-Class II) alleles; ${ }^{5}$ however, there are stronger HLA-Class II allelic associations with SScspecific autoantibodies. In a recent US study, DPB1*1301 was most associated with antitopoisomerase 1 antibody (odds ratio 14), while anticentromere antibody was associated with DQB1*0501 and DQB1*26 epi alleles. ${ }^{5}$ Anti-RNA polymerase III was associated in Caucasian and Hispanic patients with DRB1*0404, DRB1*11, and DRB1*03 alleles and in African American patients with DRB $1 * 08 .{ }^{5}$ It is unclear at present how these genetic associations relate to the pathogenesis of SSc. However, it is currently believed that a permissive genetic background coupled with an extraneous environmental trigger sets the disease in motion. Epidemiological and/or case reports have suggested SSc might be triggered by chronic occupational exposure to silica dust and organic solvents. ${ }^{6-8}$ Clustering of SSc cases close to airports in south and west London has been reported. ${ }^{9}$ This raises the question whether chronic exposure to exhaust from jet engines is also a suspected trigger for SSc onset, although this link has not been proven.

\section{Autoimmunity}

Evidence of autoimmunity is present in the majority of SSc patients at the time of onset of symptoms (such as Raynaud's phenomenon or dysphagia) heralding the onset of the disease, suggesting it precedes onset of symptomatic SSc. The autoimmune state is characterized by increased production of antibodies to not only nuclear antigens but also other cellular and noncellular antigens, including antibodies to fibrillin-1, platelet-derived growth factor (PDGF) receptor, matrix metalloproteinases (MMP) 1 and 3 , endothelial cells, and fibroblasts. ${ }^{10}$ There is also $\mathrm{T}$ cell immunity to fibroblasts, muscle cells, types I, III, and IV collagen, laminin, and low molecular weight $\mathrm{N}$-sulfated heparin sulfate. ${ }^{11,12}$ Activated $\mathrm{T}$ cells are present in peripheral blood, and levels of soluble interleukin (IL)-2 receptor are increased in patients with SSc. ${ }^{13-15}$ Notably, $\mathrm{CD} 4+{ }^{+} \mathrm{CD} 8^{+}$double positive T cells with very high IL-4 expression are found in skin and peripheral blood of SSc patients with early active disease. ${ }^{16}$ $\mathrm{T}$ regulatory cells ( $\mathrm{T}$ regs) are increased in the peripheral blood of patients with SSc but have diminished suppressive function, perhaps as a result of increased S1P and/or other 
mediators from mast cells which are known to "disarm" $\mathrm{T}$ regs. ${ }^{17-20} \mathrm{Vdelta}^{+} /$gamma/delta $\mathrm{T}$ cells are increased in lesional SSc skin, express HLA-DR and very late activation antigen alpha4 (CD49d) suggesting that Vdelta $1^{+} \mathrm{T}$ cells have homed to fibrotic SSc skin and are expanded. ${ }^{21}$ The activation of T cells in SSc appears to be antigen driven, and analysis of $\mathrm{T}$ cell receptor repertoire in multiple skin biopsies from the same SSc patient indicates they have undergone clonal expansion to a widely distributed persistent present antigen. ${ }^{22,23}$ Proliferating activated type I collagen-specific $\mathrm{CD} 25^{+} \mathrm{CD} 4{ }^{+} \mathrm{T}$ cells of the memory $\left(\mathrm{CD} 45 \mathrm{RO}^{+}\right)$phenotype were isolated from $32 \%$ of patients with SSc but from only $3.6 \%$ of healthy or disease controls. ${ }^{12}$ Further evidence of type I collagen-specific immune response in SSc patients was shown by using complementary DNA (cDNA) arrays focused on immune-related genes. It was observed that patients with dcSSc in contrast to healthy volunteers activated more immune-related genes in peripheral blood mononuclear cells cultured for 24 hours with type I collagen. ${ }^{24}$ Furthermore, a double-blind placebo control trial of oral immune tolerance induction with bovine type I collagen in patients with early and late stage dcSSc showed an improvement in the modified Rodnan skin score in late-stage dcSSc patients $(>3-10$ years duration) who were randomized to the oral collagen group versus late-state dcSSc patients receiving placebo. ${ }^{25}$

Attention has recently focused on the innate immune defense system as a facilitator or initiator of autoimmunity. Like several other autoimmune diseases, patients with SSc have increased expression of interferon (IFN) responsive genes, or an "IFN signature", although it is not clear which type of IFN is responsible for the IFN signature in SSc. ${ }^{26}$ Polyinosinic/polycytidylic acid (poly(I:C)) (a toll-like receptor [TLR] 3 ligand) was shown to induce IFN- and transforming growth factor (TGF)- $\beta$-responsive genes and TLR3 in SSc and normal dermal fibroblasts. ${ }^{27}$ Furthermore, chronic subcutaneous infusion of poly(I:C) in mice produced an inflammatory sclerotic skin thickening with increased IFN- and TGF- $\beta$ - response gene upregulation. ${ }^{27}$

Interestingly, sera or IgG from $\mathrm{SSc}$ patients can stimulate IFN- $\alpha$ production by peripheral blood mononuclear cells (PBMCs). ${ }^{28}$ Although IFN- $\alpha$ and $-\beta$ can facilitate B cell maturation, it is not clear what role if any this plays in SSc pathogenesis and how or if it relates to upregulated expression of CD19 and B cell related genes in patients with $\mathrm{SSc}^{29,30}$ or other changes in $\mathrm{B}$ cells described in patients with SSc, including expanded naïve B cells and diminished numbers of memory B cells (reviewed in a paper by Hasegawa ${ }^{31}$ ).
Studies in animal models have shown that induction of certain types of immune reactions results in SSc-like disease. For example, murine chronic graft versus host disease is a useful model to study scleroderma (skin fibrosis). It can be created by injecting cells from B10. D2 mice into irradiated $\mathrm{Balb} / \mathrm{C}$ or Balb/C rag2 $2^{--}$mice, in which there are only minor histocompatibility differences. ${ }^{32}$ This produces sclerodermalike disease within 4-6 weeks and shows fibrosis/matrix deposition, increase in myofibroblasts, autoantibody production, dermal infiltration of immune cells, and upregulation of endothelin (ET)-1 in skin and kidney tissue. Immunization of New Zealand rabbits with human type V collagen in complete Freund's adjuvant induces a SSc-like skin fibrosis with development of antinuclear antibody and anti-Scl70 antibody. ${ }^{33}$ In addition, tolerization of C57BL/6 mice with intravenous bovine type $\mathrm{V}$ collagen inhibited bleomycininduced pulmonary fibrosis. ${ }^{34}$

\section{Vascular changes in SSc}

The vascular pathology in SSc is not necessarily an inflammatory process and would better be characterized as a vasculopathy in the absence of vasculitis. The vasculopathy is a systemic process as shown by autopsy studies. ${ }^{35,36}$ The classic autopsy study by D'Angelo et al showed that SSc patients had widespread intimal proliferation in the pulmonary, coronary, and renal arteries. ${ }^{35}$ The lesions were not inflammatory, and there was intimal hyperplasia involving small and large arteries. ${ }^{35}$ Evidence of vascular injury was reported as early as 1925 and shown to be present in multiple vascular beds. ${ }^{36}$ Impaired vascular permeability and vascular tone are the earliest signs of vascular dysfunction. ${ }^{37}$ Besides the vascular injury, impaired balance of the vasoconstrictor substance ET and vasodilator substance nitric oxide play important roles in vascular dysfunction. Platelet activation and enhanced coagulation with reduced fibrinolysis contribute further to the vasculopathy in SSc. Patients with SSc who develop pulmonary hypertension and renal crisis show characteristic vascular lesions. These lesions show classic concentric intimal proliferation, marked luminal obstruction, lymphocyte infiltration, and relative paucity of plexiform lesions. ${ }^{38-41}$

The event that initiates vascular injury in patients with SSc is currently unknown. Infectious agents, cytotoxic T-cells, nitric oxide (NO)-related free radicals, and autoantibodies against endothelial cells have been implicated. ${ }^{37}$ Endothelial cell dysfunction, neural abnormalities, and intravascular defects could contribute to the impaired vascular flow. ${ }^{42}$ The vascular abnormalities of SSc discussed below are summarized in Table 2. 
Table 2 Summary of vascular abnormalities in SSc

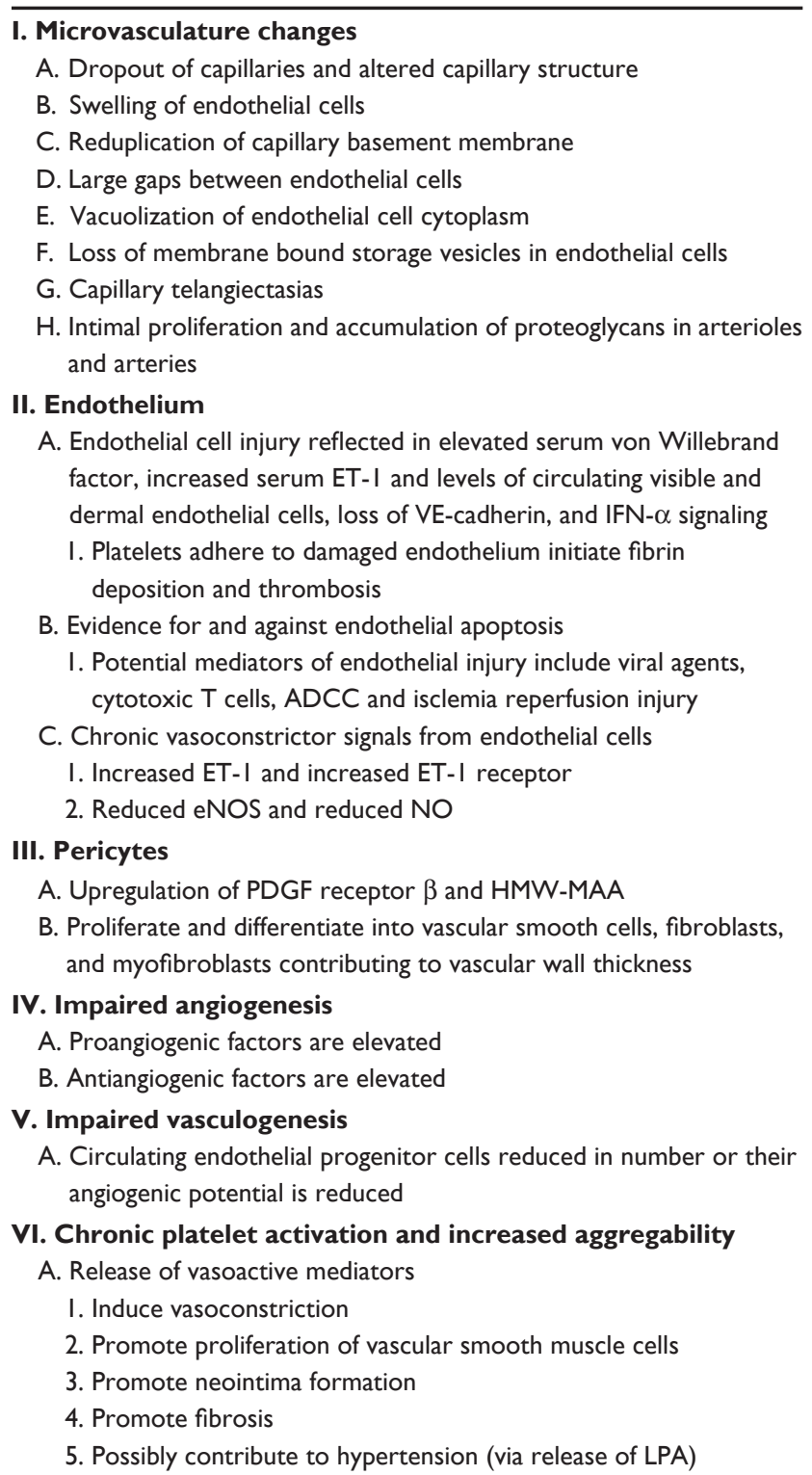

Abbreviations: ADCC, antibody dependent cellular cytotoxicity; eNOS, endothelial nitric oxide synthase; ET, endothelin; HMW-MAA, high molecular weight-melanoma associated antigen IFN, interferon; LPA, lysophosphatidic acid; NO, nitric oxide; PDGF, platelet-derived growth factor; SSc, systemic sclerosis; VE, vascular endothelial.

Microcirculatory changes involving the arterioles and the capillaries are a prominent feature of SSc. ${ }^{43}$ Abnormality of microvasculature such as dropout of capillaries as well as abnormal capillary architecture have been documented long ago ${ }^{36}$ Later studies ${ }^{44,45}$ showed similar changes which include decrease in the number of normal capillaries, swelling of endothelial cells, and reduplication of the capillary basement membrane. The earliest pathological changes in the vascular system can be seen in clinically normal skin. ${ }^{46}$ Large gaps between endothelial cells, vacuolization of endothelial cell cytoplasm, and loss of membrane-bound storage vesicles are some of the earliest detectable changes in the endothelial cells. ${ }^{46-48}$ Koenig et al showed microvascular changes to be sequential in a 20 -year follow-up study. ${ }^{49}$ Capillary enlargement is followed by capillary loss and then capillary telangiectasias. ${ }^{49}$ This is followed by morphologic changes in the vessels as well as tissue fibrosis. ${ }^{49}$ Similar changes in the capillaries are seen in all involved organs (eg, lungs, heart, kidneys, and muscles), demonstrating the widespread nature of capillary changes in SSc. ${ }^{50}$ Intimal proliferation and accumulation of proteoglycans in the arterioles and small arteries are common as well. ${ }^{51,52}$

Endothelial cell injury is an early and central event in the pathogenesis of SSc vasculopathy. ${ }^{53}$ The major evidence for the presence of the endothelial injury is high serum levels of von Willebrand factor, ${ }^{54}$ ET- $1,{ }^{55}$ and increased level of circulating viable and dead endothelial cells. ${ }^{53,56,57}$ However, it is not clear whether it is the initiating event. ${ }^{58}$ Following endothelial injury, circulating platelets adhere to subendothelial tissue and initiate fibrin deposition and intravascular thrombus formation..$^{59}$ There are conflicting reports of endothelial apoptosis. In early lesions there is endothelial cell apoptosis or changes of the endothelial cell phenotype in the absence of endothelial cell proliferation or precursor differentiation. ${ }^{60-62}$ Immature dendritic cells and macrophages may engulf apoptotic cells and subsequently present cellular antigens to $\mathrm{CD} 8^{+} \mathrm{T}$ cells, causing further tissue injury. ${ }^{63}$ These apoptotic endothelial cells can also activate the alternate complement pathway and coagulant pathway leading to vascular thrombosis. ${ }^{64,65}$ Viral agents, cytotoxic T cells, antibody dependent cellular cytotoxicity, anti-endothelial cell antibodies, and ischemia reperfusion injury are all suggested mechanisms for endothelial cell damage. ${ }^{37}$ However, Fleming et al ${ }^{60}$ failed to detect apoptotic endothelial cells in their study, although they did demonstrate loss of vascular endothelial-cadherin, which regulates endothelial barrier function, and found evidence of IFN- $\alpha$ signaling. IFN- $\alpha$ signaling suggests endoplasmic reticulum stress and the unfolded protein response in these cells. ${ }^{66,67}$

Pericytes mediate vascular maturation and stabilization during angiogenesis ${ }^{68}$ and have the potential to differentiate into vascular smooth muscle cells, fibroblasts, and myofibroblasts. ${ }^{69-71}$ They express several key cytokine receptors, including PDGF receptor $\beta$ and high molecular weight melanoma-associated antigen in vascular lesions in SSc patients with associated Raynaud's phenomenon and antinuclear antibodies. ${ }^{72}$ Another marker of angiogenic pericytes is regulator of $\mathrm{G}$ protein signaling (RGS-5) and is highly expressed in SSc vasculature. ${ }^{60}$ The exact role of 
RGS-5 is not clear, but current literature suggests that it is a negative regulator of vessel maturation. ${ }^{73}$ Pericytes proliferate and contribute to increased vascular wall thickness. ${ }^{74}$

ET-1 is released from endothelial cells and is a potent vasoconstrictor and mitogen for smooth muscle cells and fibroblasts. ${ }^{75}$ Higher levels of ET-1 have been observed in patients with scleroderma renal crisis (SRC), lung fibrosis, pulmonary hypertension, and Raynaud's phenomenon. ${ }^{76,77}$ Increased ET-1 expression is associated with increased ET- $1_{B}$ receptor in the skin and lung tissue of SSc patients. ${ }^{78}$ ET-1 is also a fibrogenic cytokine enhancing fibroblast proliferation and synthesis of types I and III collagen, while decreasing the expression of MMPs. ${ }^{79}$

$\mathrm{NO}$ is an important vasodilator of vascular smooth muscle. The release of NO from vascular endothelium sends a powerful signal to the underlying vascular smooth muscle wall. In SSc, there is a reduction in endothelial NO synthase (eNOS) gene expression and NO release in SSc and microvascular endothelial cells derived from lesional and nonlesional skin biopsies in the steady state and after shear stress. ${ }^{80}$ This is probably associated with deficient endothelium dependent relaxation in SSc. ${ }^{81}$ Impaired NO results in alteration of vascular tone, enhancement of platelet aggregation, and increased susceptibility of endothelial cells to oxidative injury. NO also limits cytokine-induced endothelial cell activation and monocyte adhesion and inhibits the endothelial cell release of IL-6 and IL-8, which are important inflammatory cytokines. ${ }^{82}$ Further, NO inhibits vascular smooth muscle cell proliferation through elevation of cyclic guanosine monophosphate (cGMP) and inhibition of mitogenic proteins TGF- $\beta$ and PDGF. Therefore, impaired NO production in SSc may contribute to the pathogenesis of arteriolar intimal proliferation and may have a prominent role in pathophysiology of the disease.

Angiogenesis is defined as the process where new vessels are formed from pre-existing ones. This depends on the activation, proliferation, and migration of endothelial cells and is driven by angiogenic stimuli that also induce proteolytic enzymes, which cleave the extracellular matrix. The remarkable loss of capillaries and small vessels in patients with SSc suggests a defect in the process of angiogenesis. Despite the reduced capillary density, there is no significant angiogenic response in SSc. Tissue ischemia usually leads to the expression of angiogenic growth factors, eg, vascular endothelial growth factor (VEGF), which causes vasodilatation, proliferation, and migration of endothelial cells, and stabilization of the lumina to form new vessels. ${ }^{83}$ Plasma levels of VEGF are elevated in SSc, and this could stimulate angiogenesis. ${ }^{83}$ Levels of other proangiogenic factors (eg, PDGF, placental growth factor, and fibroblast growth factor $[\mathrm{FGF}]-2)$ are also considerably elevated in the plasma of SSc patients. ${ }^{84}$ Expression of VEGF and its receptors VEGFR1 and VEGFR2 are increased in skin of SSc patients. ${ }^{85-87}$ In one study, ${ }^{85}$ upregulation of VEGF was not mediated by hypoxia-inducible transcription factor-1 (HIF-1) as indicated by only a weak expression of the oxygensensitive $\alpha$-subunit of HIF-1 in the skin of SSc patients. The chronic and uncontrolled overexpression of VEGF is thought to be the result of a net effect of cytokines such as IL-1 and PDGF. However, in another study, hypoxia was associated with increased VGEF level in patients with lcSSc and dcSSc as evidenced by elevation of hypoxia associated glucose transporter molecule, GLUT-1. ${ }^{87}$ In addition to elevated level of VEGF, other proangiogenic mediators such as ET-1, adhesion molecules, and chemokines are found in the circulation of SSc patients. ${ }^{32}$ Elevated levels of antiangiogenic factors such as angiostatin, platelet factor 4 (also called CXCL4), thrombospondin-1, and IL-4 have been described. ${ }^{32,88} \mathrm{At}$ the present time it is not clear whether dysregulated levels of circulating angiogenic factors or antiangiogenic factors contribute to SSc vasculopathy.

Vasculogenesis is defined as formation of new vessels from progenitor cells. Bone marrow-derived cells contribute to physiological and pathological vascular remodeling. Progenitor cells migrate to the sites of vascular injury and can differentiate to endothelial cells for vascular repair or can differentiate into vascular smooth muscle cells or foam cells contributing to neointimal proliferation and vascular disease.$^{89,90}$ The role of vasculogenesis in SSc is not clear, and there are conflicting reports regarding the presence and role of circulating endothelial progenitor cells in SSc. ${ }^{91}$ Increased levels of circulating endothelial progenitor cells have been demonstrated, which supports their mobilization from bone marrow. ${ }^{92}$ However, in another study, ${ }^{56}$ there were substantially reduced numbers of bone marrow-derived, circulating endothelial precursors compared with healthy subjects or patients with rheumatoid arthritis. The lowest number of these cells was observed in SSc patients with active fingertip ulcers, and this may suggest inadequate recruitment of these precursor cells and impaired vascular repair mechanisms. ${ }^{56}$ Atorvastatin can be effective in Raynaud's phenomenon, perhaps by increasing the number of circulating endothelial progenitor cells, ${ }^{93}$ which suggests a role of endothelial progenitor cells in vascular dysfunction. Apoptosis of endothelial progenitor cells by a circulating factor has been implicated as the potential mechanism 
for the reduced number of circulating precursor cells in SSc. ${ }^{94}$ Mesenchymal stem cells might be another source of endothelial progenitor cells. In SSc, the angiogenic potential of these cells is reduced. ${ }^{95}$ This suggests that endothelial repair may be affected by unknown SSc disease effects on the bone marrow.

Coagulation and fibrinolysis processes are dysregulated in SSc. Microvascular thrombosis and enhanced fibrin deposition are frequently seen in the vasculature of SSc patients, suggesting defective regulation of the coagulation and fibrinolytic process. The loss of balance between fibrinolysis and coagulation contributes to vessel engulfment with fibrin and breakdown of vessel patency. ${ }^{96}$ In a study of 29 SSc patients, the authors demonstrated impairment of fibrinolysis and activation of the coagulation pathway. ${ }^{96}$ Activation of the coagulation system is described by others, and elevated levels of fibrinogen and von Willebrand factor have been consistently described in SSc. ${ }^{97-100}$ Another study also found depressed fibrinolysis, expressed as defective $t$ plasminogen activator (tPA) antigen release and/or elevated tPA inhibitor (PAI) antigen, in support of a heterogeneous hypofibrinolytic pattern in SSc. ${ }^{101}$

Platelet abnormalities are seen in systemic sclerosis and play an important role in the pathogenesis of vasculopathy. Platelets are in a chronically activated state exhibiting enhanced aggregability to various triggers such as type I collagen, adenosine diphosphates, 5-hydroxy tryptamine (HT), ${ }^{102-104}$ ET-1, S1P, and LPA (reviewed in a paper by Pattanaik and Postlethwaite $\left.{ }^{105}\right)$. ET-1 induces vasoconstriction, as does S1P, by engaging S1P type 2 and 3 receptors. ${ }^{106}$ LPA induces platelet aggregation and hypertension, and promotes proliferation of vascular smooth muscle cells and neointima formation, which can induce vasospasm and Raynaud's phenomenon. ${ }^{107-110}$

There are reports in the literature that repeatedly document ongoing and chronic activation of platelets and/or release of their biologically active molecules which could contribute to the vascular, immunologic, and connective tissue pathology of SSc (reviewed in a paper by Postlethwaite and Chiang ${ }^{103}$ ). The list of bioactive molecules produced or released from platelets is very impressive and includes inflammatory mediators (NO, serotonin, thromboxane A2, LPA, S1P, prostaglandin (PG) D2, PGE2, PGF2, 12-hydroxyeicosatetraeonic acid, $\beta$ thromboglobulin, neutrophil-activating peptide-2, platelet factor-4, platelet activating factor, adenosine, histamine, P-selectin, CD40 ligand, dinucleoside polyphosphates, 2-arachidonyl glyceride, MMP-27), chemokines (macrophage inflammatory protein $1 \alpha$, monocyte chemoattractant, protein-3, IL-8, and regulated upon activation, normal T-cell expressed and secreted), cytokines (IL-1 $\beta$ and granulocyte monocyte-colony stimulating factor [GMCSF]), and growth factors (PDGF-A, -B, -C, and -D; TGF- $\beta 1$ and $-\beta 2$; epidermal growth factor; VEGF-A and -C; brain-derived neurotrophic factor; insulin-like growth factor-1; basic fibroblasts growth factor; hepatocyte growth factor; and connective tissue growth factor [CTGF]) (reviewed in a paper by Postlethwaite and Chiang ${ }^{103}$ ). Platelets from patients with SSc exhibit a signature not observed in platelets from normal donors or several other rheumatic diseases. This SSc platelet signature is overexpression of a specific nonintegrin $65 \mathrm{kDa}$ receptor for type I collagen, enhanced expression of phosphitidylinositol(PI)-3 secondary to increased nitrotyrosylation, and increased protein kinase B (Akt) activity. ${ }^{103,111}$ There is also indirect evidence that the signature may be acquired and induced by cytokines produced by $\mathrm{T}$ cells and monocytes activated by autoantigen such as type I collagen that in turn change the phenotype of megakacyocytes. ${ }^{104}$ Since platelets can chemotax to type I collagen and other chemoattractants and leave the vascular compartment, ${ }^{12-114}$ their stores of numerous fibrogenic mediators might contribute to chronic tissue fibrosis in $\mathrm{SSc}$ by release into tissue of TGF- $\beta 1$ and $-\beta 2$, PDGF-A, $-\mathrm{B},-\mathrm{C}$, and -D, lysophosphatidic acid (LPA), S1P, adenosine, basic FGF, CTGF, and insulin-like growth factor (IGF)-1. LPA and S1P, which have many biological properties and effects on a host of cells that could also facilitate and contribute to autoimmunity and fibrosis (reviewed in a paper by Pattanaik and Postlethwaite ${ }^{105}$, discussed below).

\section{Possible insights into SSc vascular changes from animal models}

Animal studies in mice recapitulate some of the vasculopathy of SSc. For example, mice with a conditional deletion of Friend leukemia integration (Fli)1 develop systemic vascular lesions characterized by capillary dilitation, vascular fragility, stenoisis of arterioles, increased vascular permeability, micro-aneurysm development, decreased expression of platelet/endothelial cell adhesion molecule (PECAM)-1, PDGF-B, and $\mathrm{S} 1 \mathrm{P}_{1}$ receptors, and increased endothelial cell MMP-9 expression. ${ }^{115}$ Sgnoc et $\mathrm{al}^{61}$ demonstrated endothelial cell apoptosis in the University of California at Davis chicken lines 200/206 which spontaneously develop an SSc-like disease.

Caveolin-1 is one of three membrane proteins that coat caveolae, which are plasma membrane invaginations 
important in clustering together of receptors that can influence signal transmission of the specific receptor ligand. ${ }^{116}$ Caveolin-1 null mice develop pulmonary arterial hypertension (PAH) and right and left ventricular enlargement and failure. ${ }^{117}$ However, in contrast to caveolin-1 null mice with $\mathrm{PAH}$, in human idopathic $\mathrm{PAH}$, there is an apparent increase in caveolin-1 expression in the pulmonary artery smooth muscle cells (PASMCs) compared with healthy controls and the overexpression of caveolin-1 increases capacitative $\mathrm{Ca}^{++}$entry and DNA synthesis in PASMC. ${ }^{118}$ The caveolin-1 null mice also develop pulmonary fibrosis, raising questions regarding the etiology of the PAH which is yet to be clearly defined. Calveolin-1 is reduced in areas of lung fibrosis and in areas of dermal fibrosis in patients with $\mathrm{SSc}$, and caveolin-null mice develop dermal fibrosis. ${ }^{116}$

\section{Fibrosis}

Fibrosis is the pathological hallmark of SSc. The fibrotic process is most prominent in the skin, lungs, GI tract, heart, tendons, and ligaments. The fibrosis is secondary to excessive deposition of extracellular-matrix (ECM) components, caused by overproduction of collagen and other glycoproteins (eg, fibronectin and fibrillin). ${ }^{119,120}$ There is an alteration of the macromolecular arrangement of collagens by cross links that are normally seen in bone but not in collagen matrix. The cross-links are formed by lysyl hydroxylase 2, the level of which is increased in scleroderma. ${ }^{121}$ Lysyl hydroxylase 2 is a key enzyme involved in the generation of hydroxylysine aldehyde-derived collagen cross-links typically found in bone tissue. ${ }^{122}$ In addition to the increased synthesis of particular matrix proteins, there is an altered composition and posttranslational modification of the ECM. ${ }^{123}$

Patients with stiff skin syndrome (SSS), an autosomal dominant congenital form of scleroderma have heterozygous missense mutations in the 4 th latent TGF- $\beta$ binding proteinlike domain of the ECM protein fibrillin-1. ${ }^{124}$ This domain harbors the only Arg-Gly-Asp sequence in fibrillin-1 that mediates matrix-cell attachments via integrin bridging. Mutation in this TGF- $\beta$ binding domain leads to altered cell-matrix interactions. Such altered cell-matrix interaction is associated with excessive microfibrillar deposition, impaired elastogenesis, and increased TGF- $\beta$ concentration and signaling in the dermis of SSc patients. Gene array analyses showed increased expression of fibrillin-1 and fibrillin-2 in scleroderma skin and lung fibrosis tissue. ${ }^{125,126}$ Fibrillin-2 is involved in matrix deposition, storage, and activation of growth factors of the TGF- $\beta$ super family. TGF- $\beta$ is secreted from cells bound to a member of the latent transforming growth factor $\beta$ binding protein family, which in turn interacts with fibrillin-1 and fibrillin-2. ${ }^{127}$ Increased fibrillin-2 expression is associated with latency associated protein TGF- $\beta$ in fibrotic tissue. Fibrillin- 2 could serve as a structural scaffold to store and release TGF- $\beta$ and could contribute to the activation of fibroblasts during fibrosis associated with SSc. ${ }^{128}$

The most abundant ECM molecule in the fibrotic process is type I collagen. Progressive replacement of normal tissue architecture by collagen rich extracellular matrix leads to organ dysfunction. Excessive connective tissue accumulation is due to excessive production by fibroblasts and other mesenchymal cells activated by various soluble mediators. Impaired ECM degradation and turnover and expansion of the pool of mesenchymal cells further contribute to the ECM accumulation. ${ }^{129}$ The exaggerated production of ECM macromolecules by the fibroblasts results from the increased transcription rates of their corresponding genes. ${ }^{130,131}$ The fibrogenic mechanisms that results in tissue fibrosis in SSc are complex and likely not due to a single growth factor/cytokine or mediator. This conclusion is reached because multiple fibrogenic mediators have been detected in SSc fibrotic tissues or in plasma/sera of patients with SSc. These include TGF- $\beta 1$ and $-\beta 2$, PDGF, IL-4, CTGF, IL-13, IL-6, oncostatin M, tryptase, IL-17, IL-5, monocyte chemoattractant protein (MCP)-1, S1P, and LPA. ${ }^{10,20,105}$ Which mediators drive fibrogenesis in SSc may also depend on disease subset type and/or disease duration. For example, analysis of gene expression using DNA arrays of biopsies from SSc lesional skin showed an inflammatory pattern that correlated with $\mathrm{T}$ cell infiltration, while a diffuse proliferative pattern correlated with increased numbers of proliferative cells in the skin. ${ }^{126}$

IL-4 and TGF- $\beta 1$ are potent chemoattractants for fibroblasts and stimulate fibroblast proliferation and collagen and fibronectin synthesis. ${ }^{132-134} \mathrm{CTGF}$ also plays an important role in fibrosis. ${ }^{135}$ Enhanced CTGF expression has been detected in SSc lesions. Serum CTGF level is markedly elevated in SSc patients compared with normal controls or patients with other autoimmune diseases, and correlates closely with the degree of skin fibrosis. ${ }^{136}$ Moreover, CTGF expression is elevated in dermal fibroblasts of SSc patients. ${ }^{137}$

TGF- $\beta$ receptor internalization and subsequent downstream signaling is regulated by caveolin- 1 , and TGF- $\beta$ receptor is rapidly degraded once it is internalized via caveolin-1 lipid rafts. ${ }^{116}$ Caveolin-1 expression is reduced in $\mathrm{SSc}$ lesional but not in nonlesional fibroblasts, and treatment of SSc fibroblast with a bioactive caveolin-1 fragment 
reduces collagen synthesis of SSc fibroblasts, inhibits TGF- $\beta$ stimulation of collagen synthesis of normal fibroblasts, and reduces lung fibrosis in mice treated with bleomycin. ${ }^{116,138}$

The degree of perivascular and tissue accumulation of $\mathrm{T}$ cells, B cells, monocytes, natural killer (NK) cells, and mast cells is variable and often present early in the disease. The cytokines, growth factors, chemokines, S1P and LPA that induce fibrosis that these different cell types release would necessarily vary as such cellular infiltrates vary. Platelets would be the most constant source of fibrogenic mediators in SSc, since they are chronically activated, and there is evidence of ongoing aggregation of platelets and release of platelet particles in SSc (reviewed in a paper by Postlethwaite and Chiang ${ }^{103}$ ). Platelets are an especially rich source of TGF- $\beta 1$ and - $\beta 2$, PDGF-A, -B, -C, and -D, IGF-1, S1P, and LPA which promote fibrosis (reviewed in papers by Postlethwaite et $\mathrm{al}^{10}$ and Postlethwaite and Chiang ${ }^{103}$ ).

The predominant fibroblast type in lesional fibrotic $\mathrm{SSc}$ skin and tissue is the myofibroblast which expresses $\alpha$ smooth muscle actin, contracts matrix, and expresses the ED-A splice variant of fibronectin. ${ }^{71}$ ED-A-containing polymerized fibronectin is necessary for the induction of the myofibroblastic phenotype by TGF- $\beta 1 .{ }^{139}$ Myofibroblast development is profoundly influenced by the mechanical microenvironment; in particular, by the organization and stiffness of the ECM. ${ }^{140}$ Myofibroblasts are not increased in nonlesional SSc tissue. Myofibroblasts can be induced from: 1) resident fibroblasts by TGF- $\beta 1$, TGF- $\beta 3$, GMCSF, IL- 6 , IL-4, thrombin, bradykinin, and histamine or tryptase from mast cells; 2) epithelial cells by oncostatin M and TGF- $\beta 1$; 3 ) endothelial cells by tumor necrosis factor- $\alpha$; 4) pericytes by TGF- $\beta 1$; and 5 ) circulating fibrocytes by TGF- $\beta 1$, IL-4, IL-13, PDGF-B, and ET- $1 .{ }^{10}$ Which of these sources is/are responsible for the predominant presence of myofibroblasts in SSc fibrotic tissue is yet to be determined. Myofibroblasts can also be induced by overexpressing in normal human dermal fibroblasts, intracellular IL-1 receptor antagonist protein (icIL-1 ra) which also renders myofibroblasts resistant to upregulation of MMP-1 synthesis. ${ }^{141}$ Intracellular IL-1 ra is also overexpressed in dermal fibroblasts grown from SSc lesional skin. ${ }^{142}$

LPA-activated chloride channel $\left(\mathrm{Icl}_{\mathrm{LPA}}\right)$ activity plays an important role in differentiation of fibroblasts to a myofibroblast phenotype, is a marker for myofibroblast phenotype, and is activated by LPA or S1P as myofibroblasts develop from fibroblasts. ${ }^{143}$ Indeed, fibroblasts grown from skin of SSc patients show significantly increased $\mathrm{ICl}_{\text {LPA }}$ activity following LPA exposure compared with healthy volunteer fibroblasts. ${ }^{143}$ Thus, these results suggest elevated $\mathrm{ICl}_{\mathrm{LPA}}$ activity is a marker of SSc skin fibroblasts. A dependency for development of fibrosis on LPA or S1P has been demonstrated in several animal models including pulmonary fibrosis, liver fibrosis, and renal interstitial fibrosis. ${ }^{144-148}$ S1P has been shown to regulate fibrosis in animal models of eye and cardiac fibrosis. ${ }^{149-151}$

\section{Relation of autoimmunity to vascular changes and fibrogenesis in SSc}

There is no single animal model that recapitulates the natural course of human SSc including autoimmune, vascular, and fibrotic changes that would allow hypothesis testing and intervention to assess the roles and interdependence of these three processes. We therefore have to speculate how these three basic pathologic processes of SSc are interconnected and which of the three processes is most likely to be able to modulate the other two in human SSc based on results of a large body of data generated in vitro and in vivo.

While Raynaud's phenomenon is an early and prominent feature in most cases of adult SSc seen in the USA, this is not the case in some racial/ethnic groups. For example, in Nigerians, Raynaud's is the presenting symptom in only $14.3 \%{ }^{152}$ Furthermore, a subset of patients with dcSSc present with diffuse skin thickening and no Raynaud's. ${ }^{153}$ This argues against vasculopathy being essential or the main driving process in effecting fibrosis in SSc. Based on what is known regarding the histology of SSc lesions and capabilities of the molecular mediators elaborated by immune and inflammatory cells and platelets, it seems most plausible that these cells and/or platelets are the most likely driving force that effects and/or contributes to fibrosis and the vasculopathy (see Figure 1).

We will briefly summarize the evidence for the central role of immune/inflammatory cells in the pathogenesis of SSc since more detailed descriptions are given in other recent reviews. ${ }^{10,105}$ The autoimmune state in SSc may partially be the result of a permissive genetic background and reduced suppressive function of T regs. ${ }^{154} \mathrm{It}$ is not apparent why T regs in SSc patients have reduced suppressive function, but it is now known that mast cells, which are increased in fibrotic skin and other tissues early in the disease process can impair suppressive function of $\mathrm{T}$ regs, and $\mathrm{S} 1 \mathrm{P}$ (which is elevated in the sera of SSc patients ${ }^{19,143}$ and produced by mast cells, platelets, macrophage/monocytes, and the endothelium) also inhibits suppressive function of T regs. ${ }^{18}$ Furthermore, both mast cells and S1P facilitate generation of Th17 T cells, 


\section{Schematic depiction of interconnection of autoimmunity, vasculopathy and fibrosis facilitated by LPA and S1P}

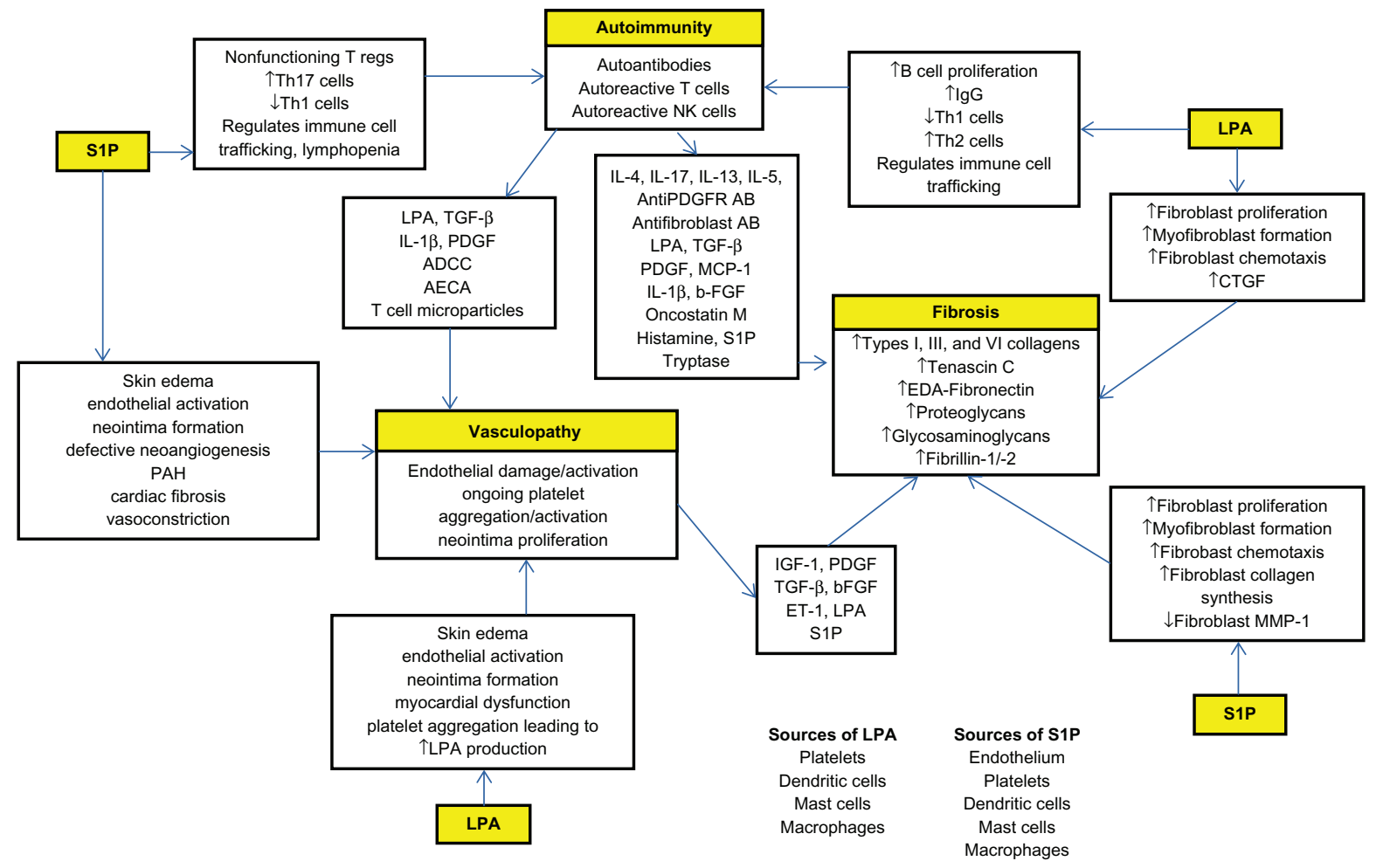

Figure I Autoimmune state develops in a permissive genetic background and is triggered by unknown factors. It results in generation of autoantibodies, autoreactive T cells, and NK cells that can elaborate a host of molecular mediators, cytokines, and growth factors. All these mediators induce vasculopathy and fibrosis (discussed in text). LPA and SIP are generated from aggregated platelets, dendritic cells, mast cells, macrophages, and endothelium. SIP may act as facilitators and promote immune/inflammatory reactions, cardiac and vascular changes, and fibrosis (discussed in text and reviewed in papers by Postlethwaite et al ${ }^{10}$ and Postlethwaite ${ }^{11}$ ).

Abbreviations: $A B$, antibody; $A D C C$, antibody dependent cellular cytotoxicity; AECA, anti-endothelial cell antibody; CTGF, connective tissue growth factor; EDA, extra domain A; ET, endothelin; FGF, fibroblast growth factor; IGF, insulin-like growth factor; IL, interleukin; LPA, lysophosphatidic acid; MCP, monocyte chemoattractant protein; MMP, matrix metalloproteinase; NK, natural killer; PAH, pulmonary arterial hypertension; PDGF, platelet-derived growth factor; PDGFR, PDGF receptor; SIP, sphingosine I-phosphate; TGF, transforming growth factor; T regs, T regulatory cells.

which elaborate IL-17, which in turn promotes inflammation and fibrosis. ${ }^{18,19,155}$ Th17 cells are increased in SSc. ${ }^{154}$ In SSc, the skewing of $\mathrm{T}$ cells toward a Th2 cytokine-producing phenotype, which is facilitated by S1P and LPA, permits production of IL-4 and IL-13 which are fibrogenic. ${ }^{105,156}$ Activated B cells in SSc patients acting as antigen-presenting cells also preferentially evoke development of Th2 cells. ${ }^{31}$ The heightened autoimmune state plus S1P and LPA elaborated by immune inflammatory cells and platelets have properties that can effect vascular changes seen in patients with SSc. $\mathrm{T}$ cell-derived microparticles generated during activation of $\mathrm{T}$ cells induces endothelial cell dysfunction and vasoconstriction with reduced eNOS expression. ${ }^{157}$ (see Figure 1).

\section{Treatment options for scleroderma vascular disease}

In this section, we will focus on the most recent therapies that are used to treat Raynaud's phenomenon, digital ulcers, and critical digital ischemia. We will also discuss current drug trials that focus on vasculopathy of SSc.

\section{Raynaud's phenomenon and digital ulcers}

Raynaud's phenomenon usually precedes skin fibrosis anywhere from months to years and in $50 \%$ of patients can result in ulceration and critical digital ischemia. The pathogenesis of vascular damage includes endothelial cell apoptosis, adhesion molecule upregulation, ischemia-reperfusion reaction, platelet activation, activation of inflammatory markers that ultimately lead to an imbalance between coagulation and fibrinolysis, ${ }^{158,159}$ with resultant alteration in capillary structure and progressive decrease in their density with slowing of blood flow and increased periods of stasis. ${ }^{160}$ Secondary Raynaud's phenomenon has pronounced vasospasm, abnormalities in blood vessel endothelium, including increased abnormalities of calcitonin gene related peptide (CGRP), 
ET, and VEGF. ${ }^{161}$ The approach to treating Raynaud's phenomenon and digital ulcers is focused on targeting these structural abnormalities by preventing the root cause of vascular damage. Such treatment includes the use of vasodilators, NO, PGs, inhibitors of phosphodiesterase, angiotensin converting enzyme (ACE) inhibitors, selective serotonin reuptake inhibitors, alpha-adrenergic blocking agents, ET receptor antagonist, statins, and inhibitors of Rho-kinase. Therapeutics targeting coagulation and oxidative stress are also being used.

\section{Therapeutics targeting impaired vasodilatation$$
\text { Calcium channel blockers (CCBs) }
$$

Blood vessels in patients with Raynaud's phenomenon have an impaired ability to vasodilate. CCBs are the mainstay therapy for Raynaud's phenomenon. Nifedipine, amlodipine, and felodipine act on smooth muscle calcium channels. Nifedipine is the most widely used and studied CCB used in secondary Raynaud's phenomenon. Both short- and longacting nifedipine have been shown to decrease vasospasm attacks by $30 \% .{ }^{161}$ Thompson and Pope performed a meta analysis of 18 randomized, placebo-controlled, and double blind trials looking at the efficacy of CCBs for the treatment for primary Raynaud's phenomenon, concluding that there is clinical improvement in the frequency and severity of ischemic attacks with a reduction in severity of symptoms by $33 \%$ during a 1 -week period. ${ }^{162}$ Fifteen percent of patients may not tolerate CCBs due to headaches, lower extremity edema, and worsening of lower esophageal sphincter function. ${ }^{163}$

\section{CGRP}

CGRP has been studied in the treatment of Raynaud's phenomenon. CGRP is synthesized and released from small, capsaicin-sensitive sensory nerves ${ }^{164}$ and interacts with G-protein-coupled receptors. This interaction results in microvascular vasodilatation and increased vascular permeability, allowing for blood flow into cold induced ischemic tissues. ${ }^{165} \mathrm{CGRP}$ is a potent vasodilator that is secreted by nerves that supply blood vessels; neurons supplying this peptide are diminished in SSc patients. ${ }^{163,166}$ Bunker et al have found that when compared with normal digital skin, digital cutaneous microvasculature response to cold was diminished in Raynaud's phenomenon patients at $20^{\circ} \mathrm{C}$ and $5^{\circ} \mathrm{C}$, suggesting a deficiency of CGRP-containing nerves are found in the distal digital skin. ${ }^{167}$ Treatment with intravenous (IV) infusion of CGRP increased blood flow in hands and fingers, in addition to increasing hand temperature compared with saline control patients. The CGRP-treated patients also had improvement in Raynaud's induced ulcers. ${ }^{166}$

\section{NO}

NO is a potent vasodilator that's synthesized from L-arginine by NO synthase (NOS). ${ }^{168} \mathrm{NO}$ causes vasodilatation via cGMP modulation. ${ }^{163}$ The use of NO has been studied in SSc-associated Raynaud's phenomenon. A double-blind crossover study using L-arginine $8 \mathrm{~g}$ daily for 28 days did not show a vascular response in skin blood flow in SSc patients with Raynaud's phenomenon when compared with a control group. ${ }^{169}$ Topical nitrates have been shown to decrease the frequency and severity of attacks. ${ }^{170,171}$ Phase III trials using topical nitroglycerin; organogel with nitroglycerin, and topical amphiMatrix (National Clinical Trial identifier: NCT0026669 and NCT00577304) are currently underway, with the outcomes being improvement in Raynaud's phenomenon assessment score, reduction in number of events, decrease in duration of events, and decrease in symptoms (http://clinicaltrials.gov). Chung et al performed a randomized controlled trial using MQX-503 nitroglycerin gel on 219 patients with either primary or secondary Raynaud's phenomenon and found that there was a $14 \%$ change in Raynaud's phenomenon condition score compared with placebo group when gel was applied immediately before or within 5 minutes of Raynaud's phenomenon episode when gel was applied up to four times daily. They found no statistical difference in the frequency, duration, or subjective assessment when compared with a placebo group. ${ }^{172}$

\section{Prostaglandins}

PG use in Raynaud's phenomenon has been studied extensively. Prostacyclin is released by endothelial cells; its binding to platelet $\mathrm{G}$ protein-coupled receptors activates cyclic adenosine monophosphate and inhibits platelet activation and myosin light chain kinase causing smooth muscle relaxation and vasodilatation by activating protein kinase A. Epoprostenol and iloprost are synthetic analogs of prostacyclin that have been shown to prevent or lessen the effects of Raynaud's attacks in patients with SSc by increasing vascular blood flow and healing ischemic digital lesions. ${ }^{173}$ Wigley et al performed a multicenter, placebocontrolled, double-blind study evaluating the efficacy of oral iloprost $50 \mu \mathrm{g}$ twice daily for the treatment of Raynaud's 
phenomenon due to SSc. In this study they found that oral iloprost was no better than placebo in the treatment of Raynaud's phenomenon. ${ }^{174}$ A Cochrane review by Pope et al summarizing seven randomized control trials concluded that IV iloprost is effective in decreasing the frequency and severity of Raynaud's phenomenon secondary to SSc and preventing or healing digital ulcers, and that oral iloprost may have less efficacy than IV iloprost. ${ }^{175}$ Cyclic IV iloprost infusion $2 \mathrm{ng} / \mathrm{kg} / \mathrm{min}$ for 5 consecutive days for 8 hours/day was able to decrease Raynaud's phenomenon severity score and control vasospastic disease. ${ }^{176}$ Low-dose iloprost therapy over 21 days was also found to be as effective as high-dose in decreasing digital ulcer frequency and duration of Raynaud's phenomenon. ${ }^{177}$ It has been suggested that iloprost acts by downregulation of endothelial cell adhesion molecules, ${ }^{176}$ reducing levels of E-selectin, vascular cell adhesion molecule (VCAM)-1, and ET-1, ${ }^{178}$ and may also act as an antioxidant. ${ }^{179}$ Chung and Fiorentino completed a pilot study of treprostinil using five patients with digital ulcers due to Raynaud's phenomenon from SSc and found that treprostinil was able to prevent the development of new digital ulcers and promote healing of baseline ulcers. ${ }^{180}$ Clinical studies with oral treprostinil diethanolamine (DISTOL-1 and DISTOL-PK) sustained release formula are currently underway (National Clinical Trial identifier NCT00775463 and NCT00848939). Side effects of prostaglandins include headache, nausea, flushing, and jaw pain. ${ }^{181}$

\section{Phosphodiesterase (PDE)}

PDEs are degradation enzymes that regulate the cGMP pathways. ${ }^{182}$ Cyclic nucleotides are second messengers in the NO signaling pathway. NO released from endothelial cells activate both membrane-bound and soluble guanylate cyclases; enzymes needed to convert guanosin triphosphate to cGMP. cGMP inhibits vasculature smooth muscle calcium channel release, reducing the concentration of intracellular calcium available for binding, and allowing for vascular smooth muscle relaxation. ${ }^{182} \mathrm{PDE}$ is also released from vascular smooth muscles and acts by degrading cGMP and counteracting the downstream effects of $\mathrm{NO}$, thereby promoting vascular constriction. PDE inhibitors block PDE effect on cGMP allowing for vascular dilatation.

Sildenafil and tadalafil are PDE5 inhibitors that have been studied in the treatment of Raynaud's phenomenon symptoms and digital ulcers. Sildenafil is a selective inhibitor of cGMP PDE5, which has been shown to decrease the frequency and duration of attacks, lower the mean Raynaud's phenomenon condition score, and increase capillary blood flow in patients who are resistant to vasodilatory therapy. ${ }^{182}$ Recently, it is has been shown to decrease digital ulcers and pain, and improve Raynaud's phenomenon symptoms. ${ }^{183-185}$ Decreases in the mean number of Raynaud's attacks and condition scores were seen after treatment with tadalafil $10 \mathrm{mg}$ daily for 12 weeks in an open-labeled study looking at 20 male patients with SSc. These same authors found that ET-1 levels were also reduced. ${ }^{186} \mathrm{~A}$ Phase II trial is currently underway for PF-00489791, a phosphodiesterase inhibitor, to evaluate efficacy of once-daily dosing in reducing vasospasm and improving symptoms and signs associated with primary and secondary Raynaud's phenomenon (National Clinical Trial identifier: NCT0109492).

\section{Therapeutics targeting impaired vasoconstriction}

Endothelial cells have a prominent role in regulating vascular tone. Disrupting the endothelial lining results in vasoconstriction due to an endogenous inhibitor of eNOS; reducing the amount of $\mathrm{NO}$ produced and resulting in vasospasm. ${ }^{163}$ In addition to having less NO, the endothelium also produces ET-1, a potent vasoconstrictor. ET-1 is a key mediator of vascular hypertrophy, proliferation, inflammation, and fibrosis. ${ }^{91}$ ET-1 is activated by angiotensin, vasopressin, and TGF- $\beta .{ }^{163}$ ET- 1 has two receptors, $\left(\mathrm{ET}_{\mathrm{A}}\right.$ and $\mathrm{ET}_{\mathrm{B}}$ ) to which it can bind. $\mathrm{ET}_{\mathrm{A}}$ receptors are found on smooth muscle cells and fibroblasts, whereas $\mathrm{ET}_{\mathrm{B}}$ are present predominantly on endothelial cells but also on smooth muscle cells, fibroblasts, and macrophages. ${ }^{160} \mathrm{ET}_{\mathrm{A}}$ and $\mathrm{ET}_{\mathrm{B}}$ receptors on smooth muscle cells mediate vasoconstriction by ET-1. Vasodilatation by the release of $\mathrm{NO}$ and prostacyclin is mediated by activation of $\mathrm{ET}_{\mathrm{B}}$ on endothelial cells. Binding to $\mathrm{ET}_{\mathrm{B}}$ receptors also reduces the levels of ET-1 by inhibition of ET converting enzyme-1. ${ }^{160}$

Endothelin receptor antagonist has been studied in the treatment of Raynaud's phenomenon and digital ulcers due to SSc. Bosentan, a dual ET-1 receptor antagonist binds specifically to $\mathrm{ET}_{\mathrm{A}}$ and $\mathrm{ET}_{\mathrm{B}}$ receptors. ${ }^{160}$ There have been two large trials evaluating the efficacy of bosentan in the treatment of Raynaud's phenomenon-induced digital ulcers. RAPIDS-1, a randomized, prospective, placebo controlled, double-blind study of 122 patients who had received bosentan $125 \mathrm{mg}$ twice daily for a total of 16 weeks had a $48 \%$ reduction in the mean number of new ulcers and improvement in hand function. There was also a significant reduction $(P<0.0075)$ in the number of new 
ulcers compared with placebo in patients who had digital ulcers at baseline and who were considered high risk for developing new ulcers. This study did not show any significant difference between treatment groups in the healing of existing ulcers. ${ }^{187}$ In RAPIDS-2, a randomized, double-blind, placebo-controlled trial of 188 patients with SSc who had at least one active digital ulcer, received bosentan $62.5 \mathrm{mg}$ twice daily for 4 weeks followed with $125 \mathrm{mg}$ twice daily for 20 weeks revealed that bosentan was able to reduce the number of new digital ulcers by $33 \%$ compared with placebo. There was no difference between healing rates, pain, and disability. In both RAPIDS-1 and RAPIDS-2, treatment-associated benefit was higher in patients with large number of digital ulcers (four or more). ${ }^{188}$ Along with the previous trial (RAPIDS-1), this study showed that use of bosentan was associated with peripheral edema and elevated transaminases. ${ }^{189}$ Other smaller studies evaluating bosentan for treatment of digital ulcers and healed ulcers also showed improvement in ulcers ${ }^{190}$ and concluded that the drug may be a safe long-term alternative for treating recurrence of digital and healed ulcers. ${ }^{191}$ In SSc-associated pulmonary hypertension, bosentan was found to decrease serum markers of endothelin activation: intercellular adhesion molecule [ICAM]-1, VCAM-1, P-selectin, and PECAM-1. ${ }^{192}$ Bosentan may act in the same manner in digital ulcers associated with SSc Raynaud's phenomenon. Sitaxentan, a selective ET $_{\mathrm{A}}$ receptor antagonist has also been shown to treat recalcitrant SSc-related digital ulcers, with improvement in pain. It was also shown to heal preexistent ulcers, with no development of new ulcers. ${ }^{193}$ Ambrisentan is currently being evaluated in lcSSc for improving blood flow to hands and feet (National Clinical Trial identifier NCT01072669). Angiotensin has both vasoconstrictive and profibrotic properties. ${ }^{163}$ Angiotensin II receptor antagonist losartan was studied in a 15-week, randomized, parallel-group, controlled trial and was found to reduce the severity and frequency of Raynaud's phenomenon. Symptomatic improvement was associated with a significant reduction in vascular soluble adhesion molecules and procollagen type $1 \mathrm{~N}$-terminal propeptide. ${ }^{194}$ A multicenter, randomized, double-blind, placebo-controlled trial evaluating ACE inhibitor, quinapril, did not show that it had any effect on frequency or severity of Raynaud's, nor did it have an effect on the occurrence of digital ulcers. ${ }^{195}$

\section{Inhibitors of Rho-kinase and tyrosine kinase}

Exposure to cold activates vasoconstriction by selectively amplifying vascular smooth muscle constriction to norepinephrine. ${ }^{163}$ Alpha-2-adrenoreceptors are increased in digital arteries. Prazosin, an $\alpha 2$-adrenergic receptor antagonist was studied in two randomized controlled crossover trials including 40 patients and was found to be modestly effective in the treatment of Raynaud's phenomenon secondary to SSc. ${ }^{196}$ A selective $\alpha 2 \mathrm{C}$ adrenergic antagonist, OPC-28326, was studied in a single-center, double-blind, placebo controlled study involving 13 patients who received oral drug at either 10 or $40 \mathrm{mg}$. Patients who received $40 \mathrm{mg}$ tended to have a shorter period of time to improve skin temperature after cold challenge. ${ }^{197}$ Bailey et al found that cooling increased vasoconstriction via activating $\alpha 2 \mathrm{C}$ adrenoreceptors and that fasudil, a rho-kinase inhibitor, was able to inhibit this cold induced constriction. ${ }^{198}$ Increase in reactive oxygen species has been suggested in the activation of Rho/Rho-kinase pathway and the upregulation of $\alpha 2 \mathrm{C}$ adrenergic receptors on smooth muscle cells. ${ }^{199}$ Preliminary results for fasudil in the treatment of Raynaud's phenomenon are yet to be published. The primary outcome for this trial is time to recover $50 \%$ and $70 \%$ of fall in baseline skin temperature, with secondary outcomes being blood flow profile change determined by Laser Doppler 60 minutes after cold challenge.

Increased protein tyrosine kinase activity has been linked to cold induced smooth muscle contraction. Cooling to $31^{\circ} \mathrm{C}$ resulted in greater arteriole contraction and greater increase in tyrosine phosphorylation in patients with Raynaud's phenomenon due to SSc as compared with control. ${ }^{200}$ Tyrosine kinase inhibitor was able to reverse the coolinginduced contraction in patients with primary Raynaud's phenomenon. ${ }^{201}$ Imatinib mesylate is a tyrosine kinase inhibitor that targets three tyrosine kinases: ABL, c-kit, and PDGF receptors. ${ }^{202}$ It competitively binds to the adenosine triphosphate-binding pocket of c-ABL and is important in downstream signaling of TGF- $\beta$ and PDGF. ${ }^{203,204}$ A Phase II pilot study of Imatinib in the treatment of refractory SSc is currently underway. This efficacy study will evaluate the change in digital ulceration at 6 months compared with baseline (National Clinical Trial identifier NCT00506831).

\section{Statins}

3-hydroxy-3-methylglutaryl-coenzyme A reductase inhibitors have been shown to improve endothelial dysfunction, decrease blood thrombogenicity, and have anti-inflammatory properties and immunomodulatory actions. ${ }^{158}$ They have been found to have a pleotrophic effect on endothelial function ${ }^{205}$ thereby retarding vascular injury, and have been studied as a possible treatment of Raynaud's phenomenon and digital 
ulcers due to Raynaud's phenomenon. Abou-Raya et al studied 84 SSc patients who were blindly randomized to receive either $40 \mathrm{mg}$ of atorvastatin or placebo for a total of 4 months. At the end of 4 months the patients that were treated with atorvastatin had a lower development of new digital ulcers compared with the placebo group. These patients also had improvement in Raynaud's phenomenon severity and pain score. There was also a significant decrease in the biomarkers for endothelial injury from baseline in the atorvastatin group, suggesting that statins are able to retard vascular injury and improve patient function. ${ }^{158}$ Recently, Kuwana et al conducted a 24-month, open-label trial to evaluate long-term effects of statins on vascular symptoms in SSc patients. In this study, eight patients received atorvastatin $10 \mathrm{mg}$ /day and had improvement in Raynaud's phenomenon with reductions in Raynaud's condition score and reduction in angiogenic factors and vascular endothelial activation biomarkers, but there was no improvement in circulating endothelial progenitor cells. Improvement was seen at both 12 and 24 months. ${ }^{206}$

\section{Therapeutics targeting reactive oxygen species}

Oxidative stress is thought to contribute to endothelial injury by perioxidation of cell membrane lipids and activation of inflammatory cascade. ${ }^{163,186,207}$ In small studies $\mathrm{N}$-acetylcysteine infusion has been shown to improve the frequency and severity of Raynaud's phenomenon and digital ulcers. ${ }^{186,207}$ Long-term and safety studies will need to be done in SSc patients with Raynaud's phenomenon and digital ulcers.

\section{Scleroderma renal crisis}

SRC almost always is characterized by new onset of significant systemic hypertension $(>150 / 85 \mathrm{~mm} \mathrm{Hg})$ and decreased renal function ( $\geq 30 \%$ reduction in estimated glomerular filtration rate [GFR]). Risk factors include early $\mathrm{dcSSc}$, presence of anti-RNA polymerase III antibody, rapidly progressive skin thickening, presence of tendon friction rubs, and recent corticosteroid use in moderate to high dose $(>15 \mathrm{mg} / \mathrm{d}){ }^{208}$ Pathogenesis of SRC is not clear. Endothelial cell injury leads to the intimal thickening of interlobular and arcuate arteries of the renal vascular system. Dysregulation of ET-1 receptor expression and fibrosis of the glomerular and interstitial compartments may lead to renal disease progression. ${ }^{209,210}$

A number of retrospective and small prospective studies have shown that ACE inhibitors are very effective in the treatment of SRC. ${ }^{211-214}$ However, ACE inhibitors should not be given prophylactically to SSc patients with normal blood pressure, since renal crisis can be masked and develop in such patients. Captopril has been the most studied agent, and there are very limited data on other ACE inhibitors and angiotensin receptor blockers. CCBs or furosemide can be added to the ACE inhibitors if blood pressure is not still controlled. ${ }^{208}$ Patients with end-stage renal disease can benefit from hemodilaysis or peritoneal dialysis. Steen and Medsger ${ }^{212}$ has noted that improvement in renal function can continue up to 18 months following the initiation of dialysis, and some patients can come off dialysis. So, evaluation for transplantation does not have to be made immediately following the onset of SRC. There is limited experience of renal transplantation in SSc. From 1987 through 1996, the UNOS registry collected data on 23,838 living and 67,183 cadaveric renal transplantations, and out of that 260 transplants had been performed for the renal diagnosis of SSc. ${ }^{215}$ Patient survival with SSc and renal failure is reduced compared with transplant recipients with other disorders, but outcomes appear to be better than in patients treated with dialysis. ${ }^{215-218}$ Renal transplant should be considered in selected cases of SSc renal crisis patients who need renal replacement therapy.

\section{Pulmonary arterial hypertension}

Pulmonary hypertension is defined as elevation of the mean pulmonary artery pressure $>25 \mathrm{~mm} \mathrm{Hg}$ at rest and can be seen in both lcSSc and dcSSc. PAH is a subset of $\mathrm{PH}$ in which the pulmonary capillary wedge pressure (PCWP) is $\leq 15 \mathrm{~mm}$ of $\mathrm{Hg}$, which suggests that elevated pulmonary arterial pressure is not due to left sided heart disease. $\mathrm{PAH}$ is believed to arise from excessive vasoconstrictive stimuli such as from thromboxane A2 (from perturbed endothelial cells or aggregated/activated platelets) and ET-1 and reduced generation of the main vasodilators, NO, and prostacyclin synthase which converts arachidonic acid to prostacyclin. The 5-year cumulative survival of SSc related to PAH is $10 \%$ compared with $80 \%$ of control SSc population without PAH. ${ }^{219}$ Predictors of PAH include presence of anticentromere antibodies, nucleolar pattern of ANA, and FVC (forced vital capacity)/DLCO (carbon monoxide diffusion lung capacity) ratio of $\geq 1.6$. PAH can be associated with early and late SSc. ${ }^{220}$ Yearly screening echocardiogram with Doppler should be performed, and diagnosis is only confirmed by right heart catheterization. The following classes of agents have been found to be beneficial in PAH. 


\section{Prostacyclins}

Prostacyclins are important mediators of PAH in SSc. Various preparations of prostacyclin analogs are available and found to be useful in clinical trials. The first to be studied was IV epoprostenol, which is given as continuous IV infusion. IV epoprostenol improved exercise capacity, functional class, and hemodynamic measures. ${ }^{221}$ However, it is reserved for severe PAH patients refractory to other measures because of higher numbers of adverse events and the difficulty of administration. ${ }^{222}$ Subcutaneous treprostinil was studied next and has been found to be useful in PAH. It improves exercise capacity and hemodynamics and reduces clinical events compared with placebo in $\mathrm{PAH}$ patients. ${ }^{223}$ Patients with PAH secondary to connective tissue disease had similar improvement. ${ }^{224}$ Inhaled iloprost has been studied as well. In a trial involving 203 patients with PAH including patients with systemic autoimmune disease, it improved hemodynamics and exercise parameters compared with placebo. ${ }^{225}$

\section{Endothelin antagonists}

Excessive ET-1 production in PAH has been targeted by development of $\mathrm{ET}_{\mathrm{B}}$ and/or $\mathrm{ET}_{\mathrm{A}}$ receptor antagonists. Bosentan is an oral antagonist of ET receptor subtypes A and B. It shows improvements of exercise capacity, functional class, and hemodynamics in patients with SSc and PAH. ${ }^{226,227}$ Bosentan also improves survival compared with historic controls in SSc patients. ${ }^{228,229}$ Based on these studies bosentan has been recommended for the treatment of PAH. ${ }^{222}$ Newer agents such as sitaxsentan and ambrisentan block the $\mathrm{ET}_{\mathrm{A}}$ receptor, and both have been shown to be effective in patients with PAH. ${ }^{230-232}$ Sitaxsentan has been evaluated in PAH associated with connective tissue disease in 42 patients, and the results were similar to that of PAH patients without any associated connective tissue disease. ${ }^{233}$ Hepatotoxicity is one of the major side effects of endothelin antagonist. ${ }^{234}$ Peripheral edema has also been reported as an adverse event of endothelin receptor antagonist.

\section{Selective phosphodiesterase inhibitors}

(PDE)-5 inhibitors such as sildenafil and tadalafil inhibit degradation of cGMP, thereby providing more cGMP for NO-mediated vasodilatation. Sildenafil is approved at a dose of $20 \mathrm{mg}$ three times daily for treating PAH. It has been shown to improve exercise capacity, hemodynamics, and New York Heart Association functional class in patients with either idiopathic or connective tissue disease-associated
PAH. ${ }^{235}$ Sildenafil has been recommended for use in SScassociated PAH if bosentan is not effective or cannot be tolerated. ${ }^{222}$ Recently, similar results were observed with another PDE-5 inhibitor, tadalafil at $40 \mathrm{mg} /$ day. $^{232}$

\section{Imatinib mesylate}

Imatinib mesylate is a selective protein tyrosine kinase inhibitor against c-abl as well as PDGF receptor. It has been shown to be effective against PAH in animal models as well as in clinical studies. ${ }^{236-239}$ It has been suggested that imatinib mesylate likely increases the expression of Fli1 transcription factor in vascular endothelial cells, which is downregulated in SSc through an epigenetic mechanism. ${ }^{240}$

\section{Serotonin inhibitors}

Inhibitors of serotonin signaling offers a possible additional means of treating PAH. Serotonin has been implicated in the pathogenesis of PAH through vasoconstriction and stimulation of pulmonary vascular smooth muscle cell proliferation. ${ }^{240}$ Pulmonary microvascular endothelial cells derived from patients with primary $\mathrm{PAH}$ produce increased levels of serotonin in vitro, which can cause hyperplasia of pulmonary artery smooth muscle cells. ${ }^{241} 5 \mathrm{HT}$ transporter inhibitors like citalopram and fluoxetine prevent the development of PAH in animal models. ${ }^{242}$ Therefore, selective serotonin reuptake inhibitors like citalopram and fluoxetine are potential candidates for treatment of PAH in patients with SSc.

\section{Conclusion}

Vascular complications secondary to $\mathrm{PH}$, renal crisis, and digital and general ischemia are important causes of morbidity and mortality in SSc. Understanding of the vascular abnormalities and the underlying pathogenic process is clearly important for providing new insights into the treatment of SSc. Recently, several pharmacologic agents have improved the management of vascular complications of SSc. Extensive fibrosis, autoimmunity, and vascular alterations play varying roles in disease manifestations of SSc. It is not clear which one of these is the initiating event and how each process modulates the other two pathologic processes. Endothelial injury is a key event in the initiation of the vasculopathy of the SSc, and both angiogenesis as well as vasculogenesis are impaired. Abnormalities of platelet activation and the coagulation system also contribute to the vascular abnormalities. Key endothelial products such as ET-1 and NO play important 
roles in the pathogenesis, and therapeutic products targeting them have been found to be useful in the treatment of digital ischemia and pulmonary hypertension. The relationship between vasculopathy and fibrosis is not clearly understood at this point. Endothelial injury and subsequent endothlialmesenchymal cell transformation leading to formation of active fibroblasts/myofibroblasts and excessive collagen accumulation have been proposed as a potential mechanism of fibrosis. LPA and S1P have many pleotropic effects that lead to changes observed in the vasculature, connective tissue, and immune system in patients with SSc, and these molecular mediators may be future therapeutic targets for treating the disease.

A clear understanding of the relationship between autoimmunity, fibrosis, and vasculopathy is important to better elucidate the pathogenic mechanism of SSc. New animal models that would combine vascular and fibrotic aspects of the disease would be helpful in this regard.

\section{Disclosure}

The authors report no conflicts of interest in this work.

\section{References}

1. Hochberg M, Silman A, Smolen J, Weinblatt M, Weisman M. Epidemiology and classification of scleroderma. In: Rheumatology. 5th ed. St. Louis: Mosby; 2010.

2. Steen VD, Medsger TA Jr. Severe organ involvement in systemic sclerosis with diffuse scleroderma. Arthritis Rheum. 2000;43(11): 2437-2444.

3. Mayes MD, Trojanowska M. Genetic factors in systemic sclerosis. Arthritis Res Ther. 2007;9 Suppl 2:S5.

4. Agarwal SK. The genetics of systemic sclerosis. Discov Med. 2010; 10(51):134-143.

5. Arnett FC, Gourh P, Shete S, et al. Major histocompatibility complex (MHC) class II alleles, haplotypes and epitopes which confer susceptibility or protection in systemic sclerosis: analyses in 1300 Caucasian, African-American and Hispanic cases and 1000 controls. Ann Rheum Dis. 2010;69(5):822-827.

6. Rodnan GP, Benedek TG, Medsger TA Jr, Cammarata RJ. The association of progressive systemic sclerosis (scleroderma) with coal miners' pneumoconiosis and other forms of silicosis. Ann Intern Med. 1967;66(2):323-334.

7. Rustin MH, Bull HA, Ziegler V, et al. Silica-associated systemic sclerosis is clinically, serologically and immunologically indistinguishable from idiopathic systemic sclerosis. Br J Dermatol. 1990;123(6): 725-734.

8. Nietert PJ, Sutherland SE, Silver RM, et al. Is occupational organic solvent exposure a risk factor for scleroderma? Arthritis Rheum. 1998; 41(6):1111-1118.

9. Silman AJ, Howard Y, Hicklin AJ, Black C. Geographical clustering of scleroderma in south and west London. Br J Rheumatol. 1990;29(2): 93-96.

10. Postlethwaite AE, Harris LJ, Raza SH, Kodura S, Akhigbe T. Pharmacotherapy of systemic sclerosis. Expert Opin Pharmacother. 2010;11(5):789-806.

11. Postlethwaite AE. Role of T cells and cytokines in effecting fibrosis. Int Rev Immunol. 1995;12(2-4):247-258.
12. Warrington KJ, Nair U, Carbone LD, Kang AH, Postlethwaite AE. Characterisation of the immune response to type I collagen in scleroderma. Arthritis Res Ther. 2006;8(4):R136.

13. Fiocco U, Rosada M, Cozzi L, et al. Early phenotypic activation of circulating helper memory $\mathrm{T}$ cells in scleroderma: correlation with disease activity. Ann Rheum Dis. 1993;52(4):272-277.

14. Freundlich B, Jimenez SA. Phenotype of peripheral blood lymphocytes in patients with progressive systemic sclerosis: activated T lymphocytes and the effect of D-penicillamine therapy. Clin Exp Immunol. 1987; 69(2):375-384.

15. Steen VD, Engel EE, Charley MR, Medsger TA Jr. Soluble serum interleukin 2 receptors in patients with systemic sclerosis. J Rheumatol. 1996;23(4):646-649.

16. Parel Y, Aurrand-Lions M, Scheja A, Dayer JM, Roosnek E, Chizzolini C. Presence of $\mathrm{CD}^{+} \mathrm{CD}^{+}$double-positive $\mathrm{T}$ cells with very high interleukin-4 production potential in lesional skin of patients with systemic sclerosis. Arthritis Rheum. 2007;56(10): 3459-3467.

17. Radstake TR, van Bon L, Broen J, et al. Increased frequency and compromised function of T regulatory cells in systemic sclerosis (SSc) is related to a diminished CD69 and TGFbeta expression. PLoS One. 2009;4(6):e5981.

18. Liu G, Burns S, Huang G, et al. The receptor S1P1 overrides regulatory T cell-mediated immune suppression through Akt-mTOR. Nat Immunol. 2009;10(7):769-777.

19. Piconese S, Gri G, Tripodo C, et al. Mast cells counteract regulatory T-cell suppression through interleukin-6 and OX40/OX40L axis toward Th17-cell differentiation. Blood. 2009;114(13):2639-2648.

20. Tokumura A, Carbone LD, Yoshioka Y, et al. Elevated serum levels of arachidonoyl-lysophosphatidic acid and sphingosine 1-phosphate in systemic sclerosis. Int J Med Sci. 2009;6(4):168-176.

21. Giacomelli R, Matucci-Cerinic M, Cipriani P, et al. Circulating Vdelta1+ T cells are activated and accumulate in the skin of systemic sclerosis patients. Arthritis Rheum. 1998;41(2):327-334.

22. Sakkas LI, Platsoucas CD. Is systemic sclerosis an antigen-driven T cell disease? Arthritis Rheum. 2004;50(6):1721-1733.

23. Sakkas LI, Xu B, Artlett CM, Lu S, Jimenez SA, Platsoucas CD. Oligoclonal $\mathrm{T}$ cell expansion in the skin of patients with systemic sclerosis. J Immunol. 2002;168(7):3649-3659.

24. Atamas SP, Luzina IG, Ingels J, et al. Stimulation with type I collagen induces changes in gene expression in peripheral blood mononuclear cells from patients with diffuse cutaneous systemic sclerosis (scleroderma). Clin Exp Immunol. 2010;161(3):426-435.

25. Postlethwaite AE, Wong WK, Clements P, et al. A multicenter, randomized, double-blind, placebo-controlled trial of oral type I collagen treatment in patients with diffuse cutaneous systemic sclerosis: I. oral type I collagen does not improve skin in all patients, but may improve skin in late-phase disease. Arthritis Rheum. 2008;58(6):1810-1822.

26. Lafyatis R, York M. Innate immunity and inflammation in systemic sclerosis. Curr Opin Rheumatol. 2009;21(6):617-622.

27. Farina GA, York MR, Di Marzio M, et al. Poly(I:C) drives type I IFNand TGFbeta-mediated inflammation and dermal fibrosis simulating altered gene expression in systemic sclerosis. J Invest Dermatol. 2010; 130(11):2583-2593.

28. Kim D, Peck A, Santer D, et al. Induction of interferon-alpha by scleroderma sera containing autoantibodies to topoisomerase I: association of higher interferon-alpha activity with lung fibrosis. Arthritis Rheum. 2008;58(7):2163-2173.

29. Whitfield ML, Finlay DR, Murray JI, et al. Systemic and cell typespecific gene expression patterns in scleroderma skin. Proc Natl Acad Sci U S A. 2003;100(21):12319-12324.

30. Sato S, Fujimoto M, Hasegawa M, Takehara K. Altered blood B lymphocyte homeostasis in systemic sclerosis: expanded naive B cells and diminished but activated memory B cells. Arthritis Rheum. 2004;50(6):1918-1927.

31. Hasegawa M. B lymphocytes: shedding new light on the pathogenesis of systemic sclerosis. J Dermatol. 2010;37(1):3-10. 
32. Koch AE, Distler O. Vasculopathy and disordered angiogenesis in selected rheumatic diseases: rheumatoid arthritis and systemic sclerosis. Arthritis Res Ther. 2007;9 Suppl 2:S3.

33. Callado MR, Viana VS, Vendramini MB, et al. Autoantibody profile in the experimental model of scleroderma induced by type $\mathrm{V}$ human collagen. Immunology. 2007;122(1):38-46.

34. Braun RK, Martin A, Shah S, et al. Inhibition of bleomycin-induced pulmonary fibrosis through pre-treatment with collagen type V. J Heart Lung Transplant. 2010;29(8):873-880.

35. D’Angelo WA, Fries JF, Masi AT, Shulman LE. Pathologic observations in systemic sclerosis (scleroderma). A study of fifty-eight autopsy cases and fifty-eight matched controls. Am J Med. 1969;46(3): 428-440.

36. Brown GE, Leary PA. Skin capillaries in scleroderma. Arch Intern Med. 1925;36:73-88

37. Kahaleh B. Vascular disease in scleroderma: mechanisms of vascular injury. Rheum Dis Clin North Am. 2008;34(1):57-71, vi.

38. Cool CD, Kennedy D, Voelkel NF, Tuder RM. Pathogenesis and evolution of plexiform lesions in pulmonary hypertension associated with scleroderma and human immunodeficiency virus infection. Hum Pathol. 1997;28(4):434-442.

39. Dorfmuller P, Humbert M, Perros F, et al. Fibrous remodeling of the pulmonary venous system in pulmonary arterial hypertension associated with connective tissue diseases. Hum Pathol. 2007;38(6): 893-902.

40. Nagai Y, Yamanaka M, Hashimoto C, et al. Autopsy case of systemic sclerosis with severe pulmonary hypertension. J Dermatol. 2007; 34(11):769-772.

41. Cannon PJ, Hassar M, Case DB, Casarella WJ, Sommers SC, LeRoy EC. The relationship of hypertension and renal failure in scleroderma (progressive systemic sclerosis) to structural and functional abnormalities of the renal cortical circulation. Medicine (Baltimore). 1974;53(1):1-46.

42. Herrick AL. Pathogenesis of Raynaud's phenomenon. Rheumatology (Oxford). 2005;44(5):587-596.

43. Trojanowska M. Cellular and molecular aspects of vascular dysfunction in systemic sclerosis. Nat Rev Rheumatol. 2010;6(8):453-460.

44. Campbell PM, LeRoy EC. Pathogenesis of systemic sclerosis: a vascular hypothesis. Semin Arthritis Rheum. 1975;4(4):351-368.

45. Michalowski R, Kudejko J. Electron microscopic observations on skeletal muscle in diffuse scleroderma. Br J Dermatol. 1966;78(1): 24-28.

46. Prescott RJ, Freemont AJ, Jones CJ, Hoyland J, Fielding P. Sequential dermal microvascular and perivascular changes in the development of scleroderma. J Pathol. 1992;166(3):255-263.

47. Fleischmajer R, Perlish JS, Shaw KV, Pirozzi DJ. Skin capillary changes in early systemic scleroderma. Electron microscopy and "in vitro" autoradiography with tritiated thymidine. Arch Dermatol. 1976;112(11):1553-1557.

48. Freemont AJ, Hoyland J, Fielding P, Hodson N, Jayson MI. Studies of the microvascular endothelium in uninvolved skin of patients with systemic sclerosis: direct evidence for a generalized microangiopathy. Br J Dermatol. 1992;126(6):561-568.

49. Koenig M, Joyal F, Fritzler MJ, et al. Autoantibodies and microvascular damage are independent predictive factors for the progression of Raynaud's phenomenon to systemic sclerosis: a twentyyear prospective study of 586 patients, with validation of proposed criteria for early systemic sclerosis. Arthritis Rheum. 2008;58(12): 3902-3912.

50. Grassi W, Core P, Carlino G, Blasetti P, Cervini M. Labial capillary microscopy in systemic sclerosis. Ann Rheum Dis. 1993;52(8): 564-569.

51. Norton WL, Nardo JM. Vascular disease in progressive systemic sclerosis (scleroderma). Ann Intern Med. 1970;73(2):317-324.

52. Fleischmajer R, Perlish JS. Capillary alterations in scleroderma. J Am Acad Dermatol. 1980;2(2):161-170.
53. Kahaleh B, Meyer O, Scorza R. Assessment of vascular involvement. Clin Exp Rheumatol. 2003;21(3 Suppl 29):S9-S14.

54. Blann AD, Illingworth K, Jayson MI. Mechanisms of endothelial cell damage in systemic sclerosis and Raynaud's phenomenon. J Rheumatol. 1993;20(8):1325-1330.

55. Schachna L, Wigley FM. Targeting mediators of vascular injury in scleroderma. Curr Opin Rheumatol. 2002;14(6):686-693.

56. Kuwana M, Okazaki Y, Yasuoka H, Kawakami Y, Ikeda Y. Defective vasculogenesis in systemic sclerosis. Lancet. 2004;364(9434): 603-610.

57. Del Papa N, Colombo G, Fracchiolla N, et al. Circulating endothelial cells as a marker of ongoing vascular disease in systemic sclerosis. Arthritis Rheum. 2004;50(4):1296-1304.

58. Fleming JN, Schwartz SM. The pathology of scleroderma vascular disease. Rheum Dis Clin North Am. 2008;34(1):41-55, vi.

59. Jimenez SA, Derk CT. Following the molecular pathways toward an understanding of the pathogenesis of systemic sclerosis. Ann Intern Med. 2004;140(1):37-50.

60. Fleming JN, Nash RA, McLeod DO, et al. Capillary regeneration in scleroderma: stem cell therapy reverses phenotype? PLoS One. 2008; 3(1):e1452.

61. Sgonc R, Gruschwitz MS, Dietrich H, Recheis H, Gershwin ME, Wick G. Endothelial cell apoptosis is a primary pathogenetic event underlying skin lesions in avian and human scleroderma. J Clin Invest. 1996;98(3):785-792.

62. Allanore Y, Batteux F, Avouac J, Assous N, Weill B, Kahan A. Levels of circulating endothelial progenitor cells in systemic sclerosis. Clin Exp Rheumatol. 2007;25(1):60-66.

63. Albert ML, Pearce SF, Francisco LM, et al. Immature dendritic cells phagocytose apoptotic cells via alphavbeta5 and CD36, and cross-present antigens to cytotoxic T lymphocytes. J Exp Med. 1998; 188(7):1359-1368

64. Greeno EW, Bach RR, Moldow CF. Apoptosis is associated with increased cell surface tissue factor procoagulant activity. Lab Invest. 1996;75(2):281-289.

65. Tsuji S, Kaji K, Nagasawa S. Activation of the alternative pathway of human complement by apoptotic human umbilical vein endothelial cells. J Biochem. 1994;116(4):794-800.

66. Gargalovic PS, Gharavi NM, Clark MJ, et al. The unfolded protein response is an important regulator of inflammatory genes in endothelial cells. Arterioscler Thromb Vasc Biol. 2006;26(11): 2490-2496.

67. Lenna S, Townsend DM, Tan FK, et al. HLA-B35 upregulates endothelin-1 and downregulates endothelial nitric oxide synthase via endoplasmic reticulum stress response in endothelial cells. J Immunol. 2010;184(9):4654-4661.

68. Jain RK. Molecular regulation of vessel maturation. Nat Med. 2003; 9(6):685-693.

69. Hirschi KK, D'Amore PA. Pericytes in the microvasculature. Cardiovasc Res. 1996;32(4):687-698.

70. Sundberg C, Ivarsson M, Gerdin B, Rubin K. Pericytes as collagenproducing cells in excessive dermal scarring. Lab Invest. 1996;74(2): 452-466.

71. Rajkumar VS, Howell K, Csiszar K, Denton CP, Black CM, Abraham DJ. Shared expression of phenotypic markers in systemic sclerosis indicates a convergence of pericytes and fibroblasts to a myofibroblast lineage in fibrosis. Arthritis Res Ther. 2005;7(5):R1113-R1123.

72. Rajkumar VS, Sundberg C, Abraham DJ, Rubin K, Black CM. Activation of microvascular pericytes in autoimmune Raynaud's phenomenon and systemic sclerosis. Arthritis Rheum. 1999;42(5):930-941.

73. Manzur M, Ganss R. Regulator of G protein signaling 5: a new player in vascular remodeling. Trends Cardiovasc Med. 2009;19(1): 26-30.

74. Helmbold P, Fiedler E, Fischer M, Marsch W. Hyperplasia of dermal microvascular pericytes in scleroderma. J Cutan Pathol. 2004;31(6): 431-440. 
75. Yanagisawa M, Kurihara H, Kimura S, et al. A novel potent vasoconstrictor peptide produced by vascular endothelial cells. Nature. 1988;332(6163):411-415.

76. Kahaleh MB. Endothelin, an endothelial-dependent vasoconstrictor in scleroderma. Enhanced production and profibrotic action. Arthritis Rheum. 1991;34(8):978-983.

77. Yamane K, Miyauchi T, Suzuki N, et al. Significance of plasma endothelin-1 levels in patients with systemic sclerosis. J Rheumatol. 1992;19(10):1566-1571.

78. Vancheeswaran R, Azam A, Black C, Dashwood MR. Localization of endothelin-1 and its binding sites in scleroderma skin. J Rheumatol. 1994;21(7):1268-1276.

79. Clozel M, Salloukh H. Role of endothelin in fibrosis and anti-fibrotic potential of bosentan. Ann Med. 2005;37(1):2-12

80. Tomita M, Fan P, Santoro T, Kahalen B. Impaired response to mechanical fluid shear stress (MFSS) by scleroderma microvascular endothelial cells from involved and uninvolved skin. Arthritis Rheum. 1997;40:297-305.

81. Anderson ME, Moore TL, Hollis S, Clark S, Jayson MI, Herrick AL. Endothelial-dependent vasodilation is impaired in patients with systemic sclerosis, as assessed by low dose iontophoresis. Clin Exp Rheumatol. 2003;21(3):403.

82. Berk BC, Abe JI, Min W, Surapisitchat J, Yan C. Endothelial atheroprotective and anti-inflammatory mechanisms. Ann N Y Acad Sci. 2001;947:93-109; discussion 109-111.

83. Distler O, Del Rosso A, Giacomelli R, et al. Angiogenic and angiostatic factors in systemic sclerosis: increased levels of vascular endothelial growth factor are a feature of the earliest disease stages and are associated with the absence of fingertip ulcers. Arthritis Res. 2002; 4(6):R11.

84. Hummers LK, Hall A, Wigley FM, Simons M. Abnormalities in the regulators of angiogenesis in patients with scleroderma. $J$ Rheumatol. 2009;36(3):576-582

85. Distler O, Distler JH, Scheid A, et al. Uncontrolled expression of vascular endothelial growth factor and its receptors leads to insufficient skin angiogenesis in patients with systemic sclerosis. Circ Res. 2004; 95(1):109-116.

86. Mackiewicz Z, Sukura A, Povilenaite D, et al. Increased but imbalanced expression of VEGF and its receptors has no positive effect on angiogenesis in systemic sclerosis skin. Clin Exp Rheumatol. 2002; 20(5):641-646.

87. Davies CA, Jeziorska M, Freemont AJ, Herrick AL. The differential expression of VEGF, VEGFR-2, and GLUT-1 proteins in disease subtypes of systemic sclerosis. Hum Pathol. 2006;37(2):190-197.

88. Mulligan-Kehoe MJ, Drinane MC, Mollmark J, et al. Antiangiogenic plasma activity in patients with systemic sclerosis. Arthritis Rheum. 2007;56(10):3448-3458.

89. Han CI, Campbell GR, Campbell JH. Circulating bone marrow cells can contribute to neointimal formation. J Vasc Res. 2001;38(2): 113-119.

90. Tanaka K, Sata M, Hirata Y, Nagai R. Diverse contribution of bone marrow cells to neointimal hyperplasia after mechanical vascular injuries. Circ Res. 2003;93(8):783-790.

91. Distler JH, Allanore Y, Avouac J, et al. EULAR Scleroderma Trials and Research group statement and recommendations on endothelial precursor cells. Ann Rheum Dis. 2009;68(2):163-168.

92. Avouac J, Juin F, Wipff J, et al. Circulating endothelial progenitor cells in systemic sclerosis: association with disease severity. Ann Rheum Dis 2008;67(10):1455-1460.

93. Kuwana M, Kaburaki J, Okazaki Y, Yasuoka H, Kawakami Y, Ikeda Y. Increase in circulating endothelial precursors by atorvastatin in patients with systemic sclerosis. Arthritis Rheum. 2006;54(6): 1946-1951.

94. Zhu S, Evans S, Yan B, et al. Transcriptional regulation of Bim by FOXO3a and Akt mediates scleroderma serum-induced apoptosis in endothelial progenitor cells. Circulation. 2008;118(21):2156-2165.
95. Cipriani P, Guiducci S, Miniati I, et al. Impairment of endothelial cell differentiation from bone marrow-derived mesenchymal stem cells: new insight into the pathogenesis of systemic sclerosis. Arthritis Rheum. 2007;56(6):1994-2004.

96. Mattuci-Cerinic M, Valentini G, Sorano GG, et al. Blood coagulation, fibrinolysis, and markers of endothelial dysfunction in systemic sclerosis. Semin Arthritis Rheum. 2003;32(5):285-295.

97. Kahaleh MB, Osborn I, LeRoy EC. Increased factor VIII/von Willebrand factor antigen and von Willebrand factor activity in scleroderma and in Raynaud's phenomenon. Ann Intern Med. 1981; 94(4 Pt 1):482-484.

98. Greaves M, Malia RG, Milford Ward A, et al. Elevated von Willebrand factor antigen in systemic sclerosis: relationship to visceral disease. Br J Rheumatol. 1988;27(4):281-285.

99. Herrick AL, Illingworth K, Blann A, Hay CR, Hollis S, Jayson MI. Von Willebrand factor, thrombomodulin, thromboxane, beta-thromboglobulin and markers of fibrinolysis in primary Raynaud's phenomenon and systemic sclerosis. Ann Rheum Dis. 1996; 55(2):122-127.

100. Goodfield MJ, Orchard MA, Rowell NR. Whole blood platelet aggregation and coagulation factors in patients with systemic sclerosis Br J Haematol. 1993;84(4):675-680.

101. Ames PR, Lupoli S, Alves J, et al. The coagulation/fibrinolysis balance in systemic sclerosis: evidence for a haematological stress syndrome. Br J Rheumatol. 1997;36(10):1045-1050.

102. Friedhoff LT, Seibold JR, Kim HC, Simester KS. Serotonin induced platelet aggregation in systemic sclerosis. Clin Exp Rheumatol. 1984;2(2):119-123.

103. Postlethwaite AE, Chiang TM. Platelet contributions to the pathogenesis of systemic sclerosis. Curr Opin Rheumatol. 2007;19(6): 574-579.

104. Chiang TM, Postlethwaite AE. A cell model system to study regulation of phosphotidylinositol 3-kinase and protein kinase B activity by cytokines/growth factors produced by type I collagen stimulated immune cells from patients with systemic sclerosis. Biochim Biophys Acta. 2007;1770(8):1181-1186.

105. Pattanaik D, Postlethwaite AE. A role for lysophosphatidic acid and sphingosine 1-phosphate in the pathogenesis of systemic sclerosis. Discov Med. 2010;10(51):161-167.

106. Igarashi J, Michel T. Sphingosine-1-phosphate and modulation of vascular tone. Cardiovasc Res. 2009;82(2):212-220.

107. Cremers B, Flesch M, Kostenis E, et al. Modulation of myocardial contractility by lysophosphatidic acid (LPA). J Mol Cell Cardiol. 2003;35(1):71-80.

108. Zhang C, Baker DL, Yasuda S, et al. Lysophosphatidic acid induces neointima formation through PPARgamma activation. J Exp Med. 2004;199(6):763-774.

109. Cheng Y, Makarova N, Tsukahara R, et al. Lysophosphatidic acidinduced arterial wall remodeling: requirement of PPARgamma but not LPA1 or LPA2 GPCR. Cell Signal. 2009;21(12):1874-1884.

110. Kandabashi T, Shimokawa H, Mukai Y, et al. Involvement of rho-kinase in agonists-induced contractions of arteriosclerotic human arteries. Arterioscler Thromb Vasc Biol. 2002;22(2):243-248.

111. Chiang TM, Postlethwaite AE. Alteration in protein kinase B (AKT) activity in platelets from patients with systemic sclerosis. Thromb Res. 2008;122(4):501-506.

112. Pitchford SC, Momi S, Baglioni S, et al. Allergen induces the migration of platelets to lung tissue in allergic asthma. Am J Respir Crit Care Med. 2008;177(6):604-612.

113. Feng D, Nagy JA, Pyne K, Dvorak HF, Dvorak AM. Platelets exit venules by a transcellular pathway at sites of F-met peptide-induced acute inflammation in guinea pigs. Int Arch Allergy Immunol. 1998; 116(3):188-195.

114. Kravis TC, Henson PM. Accumulation of platelets at sites of antigenantibody-mediated injury: a possible role for $\operatorname{IgE}$ antibody and mast cells. J Immunol. 1977;118(5):1569-1573. 
115. Asano Y, Bujor AM, Trojanowska M. The impact of Fli1 deficiency on the pathogenesis of systemic sclerosis. J Dermatol Sci. 2010;59(3): 153-162.

116. Del Galdo F, Sotgia F, de Almeida CJ, et al. Decreased expression of caveolin 1 in patients with systemic sclerosis: crucial role in the pathogenesis of tissue fibrosis. Arthritis Rheum. 2008;58(9): 2854-2865.

117. Zhao YY, Liu Y, Stan RV, et al. Defects in caveolin-1 cause dilated cardiomyopathy and pulmonary hypertension in knockout mice. Proc Natl Acad Sci U S A. 2002;99(17):11375-11380.

118. Patel HH, Zhang S, Murray F, et al. Increased smooth muscle cell expression of caveolin-1 and caveolae contribute to the pathophysiology of idiopathic pulmonary arterial hypertension. FASEB J. 2007;21(11):2970-2979.

119. LeRoy EC. Increased collagen synthesis by scleroderma skin fibroblasts in vitro: a possible defect in the regulation or activation of the scleroderma fibroblast. J Clin Invest. 1974;54(4): 880-889.

120. Eckes B, Mauch C, Huppe G, Krieg T. Differential regulation of transcription and transcript stability of pro-alpha 1(I) collagen and fibronectin in activated fibroblasts derived from patients with systemic scleroderma. Biochem J. 1996;315(Pt 2):549-554.

121. Brinckmann J, Neess CM, GaberY, et al. Different pattern of collagen cross-links in two sclerotic skin diseases: lipodermatosclerosis and circumscribed scleroderma. J Invest Dermatol. 2001;117(2): 269-273.

122. Van der Slot AJ, Zuurmond AM, Bardoel AF, et al. Identification of PLOD2 as telopeptide lysyl hydroxylase, an important enzyme in fibrosis. J Biol Chem. 2003;278(42):40967-40972.

123. Hunzelmann N, Brinckmann J. What are the new milestones in the pathogenesis of systemic sclerosis? Ann Rheum Dis. 2010;69 Suppl 1: i52-i56.

124. Loeys BL, Gerber EE, Riegert-Johnson D, et al. Mutations in fibrillin-1 cause congenital scleroderma: stiff skin syndrome. Sci Transl Med. 2010;2(23):23ra20.

125. Gardner H, Shearstone JR, Bandaru R, et al. Gene profiling of scleroderma skin reveals robust signatures of disease that are imperfectly reflected in the transcript profiles of explanted fibroblasts. Arthritis Rheum. 2006;54(6):1961-1973.

126. Milano A, Pendergrass SA, Sargent JL, et al. Molecular subsets in the gene expression signatures of scleroderma skin. PLoS One. 2008;3(7):e2696.

127. Isogai Z, Ono RN, Ushiro S, et al. Latent transforming growth factor beta-binding protein 1 interacts with fibrillin and is a microfibrilassociated protein. J Biol Chem. 2003;278(4):2750-2757.

128. Brinckmann J, Hunzelmann N, Kahle B, et al. Enhanced fibrillin-2 expression is a general feature of wound healing and sclerosis: potential alteration of cell attachment and storage of TGF-beta. Lab Invest. 2010; 90(5):739-752.

129. Varga J, Bashey RI. Regulation of connective tissue synthesis in systemic sclerosis. Int Rev Immunol. 1995;12(2-4):187-199.

130. Jimenez SA, Saitta B. Alterations in the regulation of expression of the alpha 1(I) collagen gene (COL1A1) in systemic sclerosis (scleroderma). Springer Semin Immunopathol. 1999;21(4): 397-414.

131. Trojanowska M. Molecular aspects of scleroderma. Front Biosci. 2002;7:d608-d618.

132. Raghow R, Postlethwaite AE, Keski-Oja J, Moses HL, Kang AH. Transforming growth factor-beta increases steady state levels of type I procollagen and fibronectin messenger RNAs posttranscriptionally in cultured human dermal fibroblasts. J Clin Invest. 1987;79(4): 1285-1288.

133. Postlethwaite AE, Holness MA, Katai H, Raghow R. Human fibroblasts synthesize elevated levels of extracellular matrix proteins in response to interleukin 4. J Clin Invest. 1992;90(4): 1479-1485.
134. Postlethwaite AE, Seyer JM. Fibroblast chemotaxis induction by human recombinant interleukin-4. Identification by synthetic peptide analysis of two chemotactic domains residing in amino acid sequences 70-88 and 89-122. J Clin Invest. 1991;87(6):2147-2152.

135. Leask A, Holmes A, Abraham DJ. Connective tissue growth factor: a new and important player in the pathogenesis of fibrosis. Curr Rheumatol Rep. 2002;4(2):136-142.

136. Sato S, Nagaoka T, Hasegawa M, et al. Serum levels of connective tissue growth factor are elevated in patients with systemic sclerosis: association with extent of skin sclerosis and severity of pulmonary fibrosis. J Rheumatol. 2000;27(1):149-154.

137. Igarashi A, Nashiro K, Kikuchi K, et al. Significant correlation between connective tissue growth factor gene expression and skin sclerosis in tissue sections from patients with systemic sclerosis. J Invest Dermatol. 1995;105(2):280-284.

138. Tourkina E, Richard M, Gooz P, et al. Antifibrotic properties of caveolin-1 scaffolding domain in vitro and in vivo. Am J Physiol Lung Cell Mol Physiol. 2008;294(5):L843-L861.

139. Serini G, Bochaton-Piallat ML, Ropraz P, et al. The fibronectin domain ED-A is crucial for myofibroblastic phenotype induction by transforming growth factor-beta1. J Cell Biol. 1998;142(3):873-881.

140. Hinz B, Gabbiani G. Cell-matrix and cell-cell contacts of myofibroblasts: role in connective tissue remodeling. Thromb Haemost. 2003;90(6):993-1002.

141. Kanangat S, Postlethwaite AE, Higgins GC, Hasty KA. Novel functions of intracellular IL-1ra in human dermal fibroblasts: implications in the pathogenesis of fibrosis. J Invest Dermatol. 2006;126(4): 756-765.

142. Higgins GC, Wu Y, Postlethwaite AE. Intracellular IL-1 receptor antagonist is elevated in human dermal fibroblasts that overexpress intracellular precursor IL-1 alpha. J Immunol. 1999;163(7): 3969-3975.

143. Yin Z, Carbone LD, Gotoh M, et al. Lysophosphatidic acid-activated Cl- current activity in human systemic sclerosis skin fibroblasts. Rheumatology (Oxford). 2010;49(12):2290-2297.

144. Pradere JP, Gonzalez J, Klein J, et al. Lysophosphatidic acid and renal fibrosis. Biochim Biophys Acta. 2008;1781(9):582-587.

145. Pradere JP, Klein J, Gres S, et al. LPA1 receptor activation promotes renal interstitial fibrosis. J Am Soc Nephrol. 2007;18(12):3110-3118.

146. Tangkijvanich P, Melton AC, Chitapanarux T, Han J, Yee HF. Plateletderived growth factor-BB and lysophosphatidic acid distinctly regulate hepatic myofibroblast migration through focal adhesion kinase. Exp Cell Res. 2002;281(1):140-147.

147. Watanabe N, Ikeda H, Nakamura K, et al. Plasma lysophosphatidic acid level and serum autotaxin activity are increased in liver injury in rats in relation to its severity. Life Sci. 2007;81(12): 1009-1015.

148. Tager AM, LaCamera P, Shea BS, et al. The lysophosphatidic acid receptor LPA1 links pulmonary fibrosis to lung injury by mediating fibroblast recruitment and vascular leak. Nat Med. 2008;14(1): 45-54.

149. Ikeda H, Watanabe N, Ishii I, et al. Sphingosine 1-phosphate regulates regeneration and fibrosis after liver injury via sphingosine 1-phosphate receptor 2. J Lipid Res. 2009;50(3):556-564.

150. Swaney JS, Moreno KM, Gentile AM, Sabbadini RA, Stoller GL. Sphingosine-1-phosphate (S1P) is a novel fibrotic mediator in the eye. Exp Eye Res. 2008;87(4):367-375.

151. Gellings Lowe N, Swaney JS, Moreno KM, Sabbadini RA. Sphingosine-1-phosphate and sphingosine kinase are critical for transforming growth factor-beta-stimulated collagen production by cardiac fibroblasts. Cardiovasc Res. 2009;82(2):303-312.

152. Adelowo OO, Oguntona S. Scleroderma (systemic sclerosis) among Nigerians. Clin Rheumatol. 2009;28(9):1121-1125.

153. Chowdhury SU, Miah MA, Mahmud MI, Talukder SI, Islam MN, Islam N. Unusual presentation of progressive systemic sclerosis. Mymensingh Med J. 2008;17(2):192-196. 
154. Radstake TR, van Bon L, Broen J, et al. The pronounced Th17 profile in systemic sclerosis $(\mathrm{SSc})$ together with intracellular expression of TGFbeta and IFNgamma distinguishes SSc phenotypes. PLoS One. 2009;4(6):e5903.

155. Liao JJ, Huang MC, Goetzl EJ. Cutting edge: Alternative signaling of Th17 cell development by sphingosine 1-phosphate. J Immunol. 2007;178(9):5425-5428.

156. Gabrielli A, Avvedimento EV, Krieg T. Scleroderma. $N$ Engl J Med. 2009;360(19):1989-2003.

157. Martin S, Tesse A, Hugel B, et al. Shed membrane particles from $\mathrm{T}$ lymphocytes impair endothelial function and regulate endothelial protein expression. Circulation. 2004;109(13):1653-1659.

158. Abou-Raya A, Abou-Raya S, Helmii M. Statins: potentially useful in therapy of systemic sclerosis-related Raynaud's phenomenon and digital ulcers. J Rheumatol. 2008;35(9):1801-1808.

159. Matucci-Cerinic M, Seibold JR. Digital ulcers and outcomes assessment in scleroderma. Rheumatology (Oxford). 2008;47 Suppl 5: v46-v47.

160. Dhillon S. Bosentan: a review of its use in the management of digital ulcers associated with systemic sclerosis. Drugs. 2009;69(14): 2005-2024

161. Pope JE. The diagnosis and treatment of Raynaud's phenomenon: a practical approach. Drugs. 2007;67(4):517-525.

162. Thompson AE, Pope JE. Calcium channel blockers for primary Raynaud's phenomenon: a meta-analysis. Rheumatology (Oxford). 2005;44(2):145-150.

163. Bakst R, Merola JF, Franks AG Jr, Sanchez M. Raynaud's phenomenon: pathogenesis and management. J Am Acad Dermatol. 2008;59(4):633-653.

164. Feuerstein G, Willette R, Aiyar N. Clinical perspectives of calcitonin gene related peptide pharmacology. Can J Physiol Pharmacol. 1995; 73(7):1070-1074

165. Fonseca C, Abraham D, Ponticos M. Neuronal regulators and vascular dysfunction in Raynaud's phenomenon and systemic sclerosis. Curr Vasc Pharmacol. 2009;7(1):34-39.

166. Bunker CB, Reavley C, O’Shaughnessy DJ, Dowd PM. Calcitonin gene-related peptide in treatment of severe peripheral vascular insufficiency in Raynaud's phenomenon. Lancet. 1993;342(8863): 80-83.

167. Bunker CB, Goldsmith PC, Leslie TA, Hayes N, Foreman JC, Dowd PM. Calcitonin gene-related peptide, endothelin-1, the cutaneous microvasculature and Raynaud's phenomenon. Br J Dermatol. 1996;134(3):399-406.

168. Dooley A, Gao B, Bradley N, et al. Abnormal nitric oxide metabolism in systemic sclerosis: increased levels of nitrated proteins and asymmetric dimethylarginine. Rheumatology (Oxford). 2006;45(6): 676-684.

169. Khan F, Belch JJ. Skin blood flow in patients with systemic sclerosis and Raynaud's phenomenon: effects of oral L-arginine supplementation. J Rheumatol. 1999;26(11):2389-2394.

170. Teh LS, Manning J, Moore T, Tully MP, O’Reilly D, Jayson MI. Sustained-release transdermal glyceryl trinitrate patches as a treatment for primary and secondary Raynaud's phenomenon. Br J Rheumatol. 1995;34(7):636-641.

171. Franks AG Jr. Topical glyceryl trinitrate as adjunctive treatment in Raynaud's disease. Lancet. 1982;1(8263):76-77.

172. Chung L, Shapiro L, Fiorentino D, et al. MQX-503, a novel formulation of nitroglycerin, improves the severity of Raynaud's phenomenon: a randomized, controlled trial. Arthritis Rheum. 2009;60(3): $870-877$.

173. Leighton C. Drug treatment of scleroderma. Drugs. 2001;61(3): 419-427.

174. Wigley FM, Korn JH, Csuka ME, et al. Oral iloprost treatment in patients with Raynaud's phenomenon secondary to systemic sclerosis: a multicenter, placebo-controlled, double-blind study. Arthritis Rheum. 1998;41(4):670-677.
175. Pope J, Fenlon D, Thompson A, et al. Iloprost and cisaprost for Raynaud's phenomenon in progressive systemic sclerosis. Cochrane Database Syst Rev. 2000;2:CD000953.

176. Della Bella S, Molteni M, Mocellin C, Fumagalli S, Bonara P, Scorza R. Novel mode of action of iloprost: in vitro down-regulation of endothelial cell adhesion molecules. Prostaglandins. 2001;65(2-3): 73-83.

177. Kawald A, Burmester GR, Huscher D, Sunderkotter C, Riemekasten G. Low versus high-dose iloprost therapy over 21 days in patients with secondary Raynaud's phenomenon and systemic sclerosis: a randomized, open, single-center study. J Rheumatol. 2008;35(9):1830-1837.

178. Rehberger P, Beckheinrich-Mrowka P, Haustein UF, Sticherling M. Prostacyclin analogue iloprost influences endothelial cell-associated soluble adhesion molecules and growth factors in patients with systemic sclerosis: a time course study of serum concentrations. Acta Derm Venereol. 2009;89(3):245-249.

179. Erre GL, Passiu G. Antioxidant effect of Iloprost: current knowledge and therapeutic implications for systemic sclerosis. Reumatismo. 2009; 61(2):90-97.

180. Chung L, Fiorentino D. Digital ulcers in patients with systemic sclerosis. Autoimmun Rev. 2006;5(2):125-128.

181. Hummers LK, Wigley FM. Management of Raynaud's phenomenon and digital ischemic lesions in scleroderma. Rheum Dis Clin North Am. 2003;29(2):293-313.

182. Fries R, Shariat K, von Wilmowsky H, Bohm M. Sildenafil in the treatment of Raynaud's phenomenon resistant to vasodilatory therapy. Circulation. 2005;112(19):2980-2985.

183. Kumar N, Griffiths B, Allen J. Thermographic and symptomatic effect of a single dose of sildenafil citrate on Raynaud's phenomenon in patients with systemic sclerosis: a potential treatment. J Rheumatol. 2006;33(9):1918-1919.

184. Brueckner CS, Becker MO, Kroencke T, et al. Effect of sildenafil on digital ulcers in systemic sclerosis: analysis from a single centre pilot study. Ann Rheum Dis. 2010;69(8):1475-1478.

185. De LaVega AJ, Derk CT. Phosphodiesterase-5 inhibitors for the treatment of Raynaud's: a novel indication. Expert Opin Investig Drugs. 2009;18(1):23-29.

186. Rosato E, Borghese F, Pisarri S, Salsano F. The treatment with $\mathrm{N}$-acetylcysteine of Raynaud's phenomenon and ischemic ulcers therapy in sclerodermic patients: a prospective observational study of 50 patients. Clin Rheumatol. 2009;28(12):1379-1384.

187. Korn JH, Mayes M, Matucci Cerinic M, et al. Digital ulcers in systemic sclerosis: prevention by treatment with bosentan, an oral endothelin receptor antagonist. Arthritis Rheum. 2004;50(12):3985-3993.

188. Bredemeier M. A higher degree of criticism about the effectiveness of bosentan for digital ulcers in scleroderma patients, as for interstitial disease, is also necessary: Comment on the article by Seibold et al. Arthritis Rheum. 2010;62:3128-3129.

189. Matucci-Cerinic M, Denton CP, Furst DE, et al. Bosentan treatment of digital ulcers related to systemic sclerosis: results from the RAPIDS-2 randomised, double-blind, placebo-controlled trial. Ann Rheum Dis. 2011;70(1):32-38.

190. Launay D, Diot E, Pasquier E, et al. Bosentan for treatment of active digital ulcers in patients with systemic sclerosis. Presse Med. 2006;35(4 Pt 1):587-592.

191. Garcia de la Pena-Lefebvre P, Rodriguez Rubio S, Valero Exposito M, et al. Long-term experience of bosentan for treating ulcers and healed ulcers in systemic sclerosis patients. Rheumatology (Oxford). 2008;47(4):464-466.

192. Iannone F, Riccardi MT, Guiducci S, et al. Bosentan regulates the expression of adhesion molecules on circulating $\mathrm{T}$ cells and serum soluble adhesion molecules in systemic sclerosis-associated pulmonary arterial hypertension. Ann Rheum Dis. 2008;67(8):1121-1126.

193. Gholam P, Sehr T, Enk A, Hartmann M. Successful treatment of systemicsclerosis-related digital ulcers with a selective endothelin type A receptor antagonist (sitaxentan). Dermatology. 2009;219(2): 171-173. 
194. Dziadzio M, Denton CP, Smith R, et al. Losartan therapy for Raynaud's phenomenon and scleroderma: clinical and biochemical findings in a fifteen-week, randomized, parallel-group, controlled trial. Arthritis Rheum. 1999;42(12):2646-2655.

195. Gliddon AE, Dore CJ, Black CM, et al. Prevention of vascular damage in scleroderma and autoimmune Raynaud's phenomenon: a multicenter, randomized, double-blind, placebo-controlled trial of the angiotensin-converting enzyme inhibitor quinapril. Arthritis Rheum. 2007;56(11):3837-3846.

196. Pope J, Fenlon D, Thompson A, et al. Prazosin for Raynaud's phenomenon in progressive systemic sclerosis. Cochrane Database Syst Rev. 2000(2):CD000956.

197. Wise RA, Wigley FM, White B, et al. Efficacy and tolerability of a selective alpha(2C)-adrenergic receptor blocker in recovery from coldinduced vasospasm in scleroderma patients: a single-center, doubleblind, placebo-controlled, randomized crossover study. Arthritis Rheum. 2004;50(12):3994-4001.

198. Bailey SR, Eid AH, Mitra S, Flavahan S, Flavahan NA. Rho kinase mediates cold-induced constriction of cutaneous arteries: role of alpha2C-adrenoceptor translocation. Circ Res. 2004;94(10): 1367-1374.

199. Boin F, Wigley FM. Understanding, assessing and treating Raynaud's phenomenon. Curr Opin Rheumatol. 2005;17(6):752-760.

200. Furspan PB, Chatterjee S, Mayes MD, Freedman RR. Cooling-induced contraction and protein tyrosine kinase activity of isolated arterioles in secondary Raynaud's phenomenon. Rheumatology (Oxford). 2005; 44(4):488-494.

201. Furspan PB, Chatterjee S, Freedman RR. Increased tyrosine phosphorylation mediates the cooling-induced contraction and increased vascular reactivity of Raynaud's disease. Arthritis Rheum. 2004;50(5):1578-1585.

202. Lyseng-Williamson K, Jarvis B. Imatinib. Drugs. 2001;61(12): 1765-1774; discussion 1775-1766.

203. Ramos-Casals M, Fonollosa-Pla V, Brito-Zeron P, Siso-Almirall A. Targeted therapy for systemic sclerosis: how close are we? Nat Rev Rheumatol. May;6(5):269-278.

204. Distler JH, Distler O. Intracellular tyrosine kinases as novel targets for anti-fibrotic therapy in systemic sclerosis. Rheumatology (Oxford). Oct 2008;47 Suppl 5:v10-v11.

205. Furukawa S, Yasuda S, Amengual O, Horita T, Atsumi T, Koike T. Protective effect of pravastatin on vascular endothelium in patients with systemic sclerosis: a pilot study. Ann Rheum Dis. 2006;65(8): 1118-1120.

206. Kuwana M, Okazaki Y, Kaburaki J. Long-term beneficial effects of statins on vascular manifestations in patients with systemic sclerosis. Mod Rheumatol. 2009;19(5):530-535.

207. Sambo P, Amico D, Giacomelli R, et al. Intravenous N-acetylcysteine for treatment of Raynaud's phenomenon secondary to systemic sclerosis: a pilot study. J Rheumatol. 2001;28(10):2257-2262.

208. Khanna D. Diagnosis and management of systemic sclerosis. Indian J Rheumatol. 2010;5:69-75.

209. Lee S, Sharma K. The pathogenesis of fibrosis and renal disease in scleroderma: recent insights from glomerulosclerosis. Curr Rheumatol Rep. 2004;6(2):141-148.

210. Kobayashi H, Nishimaki T, Kaise S, Suzuki T, Watanabe K, Kasukawa R. Immunohistological study endothelin-1 and endothelin-A and $\mathrm{B}$ receptors in two patients with scleroderma renal crisis. Clin Rheumatol. 1999;18(5):425-427.

211. Penn H, Howie AJ, Kingdon EJ, et al. Scleroderma renal crisis: patient characteristics and long-term outcomes. QJM. 2007;100(8): 485-494.

212. Steen VD, Medsger TA Jr. Long-term outcomes of scleroderma renal crisis. Ann Intern Med. 2000;133(8):600-603.

213. Steen VD, Costantino JP, Shapiro AP, Medsger TA Jr. Outcome of renal crisis in systemic sclerosis: relation to availability of angiotensin converting enzyme (ACE) inhibitors. Ann Intern Med. 1990;113(5): $352-357$.
214. Beckett VL, Donadio JV Jr, Brennan LA Jr, et al. Use of captopril as early therapy for renal scleroderma: a prospective study. Mayo Clin Proc. 1985;60(11):763-771.

215. Bleyer AJ, Donaldson LA, McIntosh M, Adams PL. Relationship between underlying renal disease and renal transplantation outcome. Am J Kidney Dis. 2001;37(6):1152-1161.

216. Chang YJ, Spiera H. Renal transplantation in scleroderma. Medicine (Baltimore). 1999;78(6):382-385.

217. Pham PT, Pham PC, Danovitch GM, et al. Predictors and risk factors for recurrent scleroderma renal crisis in the kidney allograft: case report and review of the literature. Am J Transplant. 2005;5(10): 2565-2569.

218. Gibney EM, Parikh CR, Jani A, Fischer MJ, Collier D, Wiseman AC. Kidney transplantation for systemic sclerosis improves survival and may modulate disease activity. Am J Transplant. 2004;4(12): 2027-2031.

219. Stupi AM, Steen VD, Owens GR, Barnes EL, Rodnan GP, Medsger TA Jr. Pulmonary hypertension in the CREST syndrome variant of systemic sclerosis. Arthritis Rheum. 1986;29(4):515-524.

220. Hachulla E, Launay D, Mouthon L, et al. Is pulmonary arterial hypertension really a late complication of systemic sclerosis? Chest. 2009;136(5):1211-1219.

221. Badesch DB, Tapson VF, McGoon MD, et al. Continuous intravenous epoprostenol for pulmonary hypertension due to the scleroderma spectrum of disease. A randomized, controlled trial. Ann Intern Med. 2000;132(6):425-434.

222. Kowal-Bielecka O, Landewe R, Avouac J, et al. EULAR recommendations for the treatment of systemic sclerosis: a report from the EULAR Scleroderma Trials and Research group (EUSTAR). Ann Rheum Dis. 2009;68(5):620-628.

223. Barst RJ, Galie N, Naeije R, et al. Long-term outcome in pulmonary arterial hypertension patients treated with subcutaneous treprostinil. Eur Respir J. 2006;28(6):1195-1203.

224. Oudiz RJ, Schilz RJ, Barst RJ, et al. Treprostinil, a prostacyclin analogue, in pulmonary arterial hypertension associated with connective tissue disease. Chest. 2004;126(2):420-427.

225. Olschewski H, Simonneau G, Galie N, et al. Inhaled iloprost for severe pulmonary hypertension. $N$ Engl J Med. 2002;347(5):322-329.

226. Channick RN, Simonneau G, Sitbon O, et al. Effects of the dual endothelin-receptor antagonist bosentan in patients with pulmonary hypertension: a randomised placebo-controlled study. Lancet. 2001; 358(9288):1119-1123.

227. Rubin LJ, Badesch DB, Barst RJ, et al. Bosentan therapy for pulmonary arterial hypertension. N Engl J Med. 2002;346(12):896-903.

228. McLaughlin VV. Survival in patients with pulmonary arterial hypertension treated with first-line bosentan. Eur J Clin Invest. 2006; 36 Suppl 3:10-15.

229. Williams MH, Das C, Handler CE, et al. Systemic sclerosis associated pulmonary hypertension: improved survival in the current era. Heart. 2006;92(7):926-932.

230. Barst RJ, Langleben D, Frost A, et al. Sitaxsentan therapy for pulmonary arterial hypertension. Am J Respir Crit Care Med. 2004; 169(4):441-447.

231. Barst RJ, Langleben D, Badesch D, et al. Treatment of pulmonary arterial hypertension with the selective endothelin-A receptor antagonist sitaxsentan. J Am Coll Cardiol. 2006;47(10):2049-2056.

232. Galie N, Brundage BH, Ghofrani HA, et al. Tadalafil therapy for pulmonary arterial hypertension. Circulation. 2009;119(22): 2894-2903.

233. Girgis RE, Frost AE, Hill NS, et al. Selective endothelin A receptor antagonism with sitaxsentan for pulmonary arterial hypertension associated with connective tissue disease. Ann Rheum Dis. 2007; 66(11):1467-1472.

234. Humbert M. The burden of pulmonary hypertension. Eur Respir J. 2007;30(1):1-2.

235. Badesch DB, Hill NS, Burgess G, et al. Sildenafil for pulmonary arterial hypertension associated with connective tissue disease. J Rheumatol. 2007;34(12):2417-2422. 
236. Ghofrani HA, Seeger W, Grimminger F. Imatinib for the treatment of pulmonary arterial hypertension. $N$ Engl J Med. 2005;353(13): 1412-1413.

237. Patterson KC, Weissmann A, Ahmadi T, Farber HW. Imatinib mesylate in the treatment of refractory idiopathic pulmonary arterial hypertension. Ann Intern Med. 2006;145(2):152-153.

238. Perros F, Montani D, Dorfmuller P, et al. Platelet-derived growth factor expression and function in idiopathic pulmonary arterial hypertension. Am J Respir Crit Care Med. 2008;178(1):81-88.

239. Schermuly RT, Dony E, Ghofrani HA, et al. Reversal of experimental pulmonary hypertension by PDGF inhibition. J Clin Invest. 2005; 115(10):2811-2821.
240. Asano Y. Future treatments in systemic sclerosis. J Dermatol. 2010;37(1):54-70.

241. Eddahibi S, Guignabert C, Barlier-Mur AM, et al. Cross talk between endothelial and smooth muscle cells in pulmonary hypertension: critical role for serotonin-induced smooth muscle hyperplasia. Circulation. 2006;113(15):1857-1864.

242. Marcos E, Adnot S, Pham MH, et al. Serotonin transporter inhibitors protect against hypoxic pulmonary hypertension. Am J Respir Crit Care Med. 2003;168(4):487-493.

\section{Publish your work in this journal}

The Journal of Inflammation Research is an international, peer-reviewed open-access journal that welcomes laboratory and clinical findings on the molecular basis, cell biology and pharmacology of inflammation including original research, reviews, symposium reports, hypothesis formation and commentaries on: acute/chronic inflammation; mediators of inflamma-

\section{Dovepress}

tion; cellular processes; molecular mechanisms; pharmacology and novel anti-inflammatory drugs; clinical conditions involving inflammation. The manuscript management system is completely online and includes a very quick and fair peer-review system. Visit http://www.dovepress.com/ testimonials.php to read real quotes from published authors.

Submit your manuscript here: http://www.dovepress.com/journal-of-inflammation-research-journal 